\title{
Dye-Sensitized Solar Cell for Indoor Applications: A Mini-Review
}

\author{
DHEERAJ DEVADIGA, ${ }^{1}$ M. SELVAKUMAR $\odot,{ }^{1,3}$ PRAKASHA SHETTY, ${ }^{1}$ \\ and M.S. SANTOSH ${ }^{2}$
}

1.-Department of Chemistry, Manipal Institute of Technology, Manipal Academy of higher education, Manipal, Karnataka 576104, India. 2.-Centre for Incubation, Innovation, Research, and Consultancy (CIIRC), Jyothy Institute of Technology, Tataguni, Off Kanakapura Road, Bangalore, Karnataka 560082, India. 3.—e-mail: chemselva@rediffmail.com

Lightweight computing technologies such as the Internet of Things and flexible wearable systems have penetrated our everyday lives exponentially in recent years. Without a question, the running of such electronic devices is a major energy problem. Generally, these devices need power within the range of microwatts and operate mostly indoors. Thus, it is appropriate to have a self-sustainable power source, such as the photovoltaic (PV) cell, which can harvest indoor light. Among other PV cells, the dye-sensitized solar cell (DSSC) has immense capacity to satisfy the energy demands of most indoor electronics, making it a very attractive power candidates because of its many benefits such as readily available materials, relatively cheap manufacturing methods, roll-to-roll compatibility, easy processing capabilities on flexible substrates and exceptional diffuse/low-light performance. This review discusses the recent developments in DSSC materials for its indoor applications. Ultimately, the perspective on this topic is presented after summing up the current progress of the research.

\section{Graphic abstract}

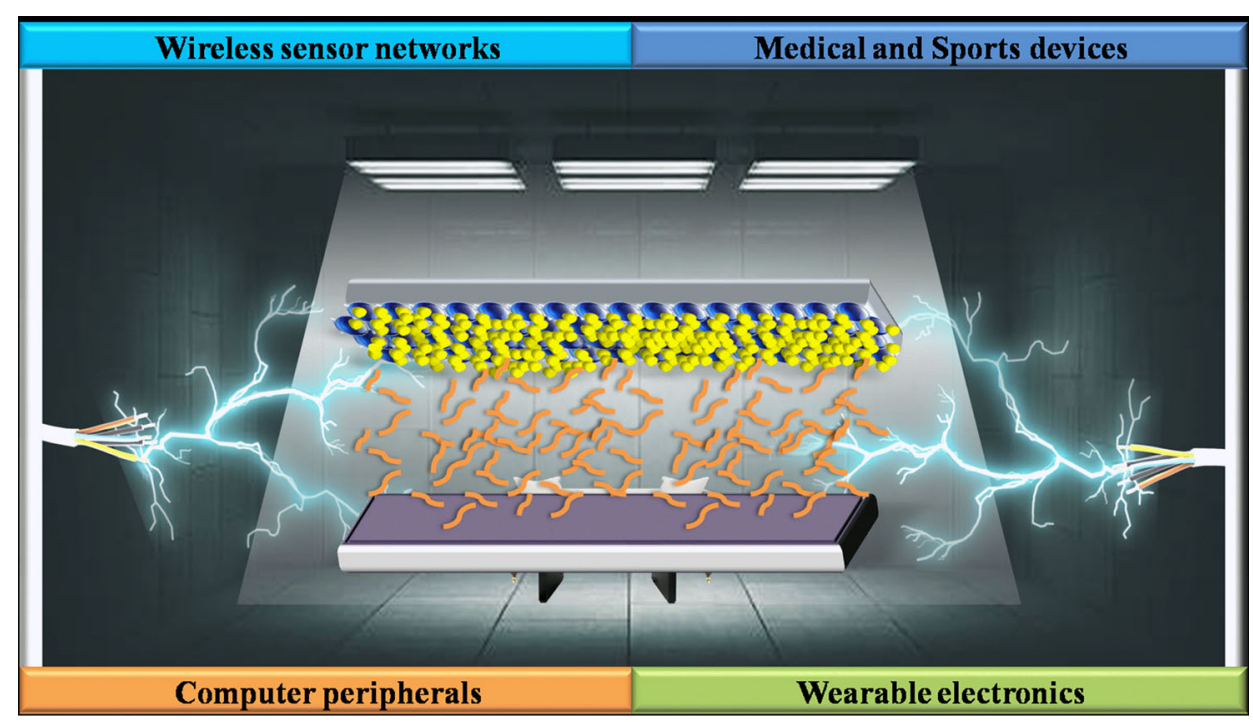

(Received November 4, 2020; accepted February 27, 2021;

published online April 1, 2021) 
Key words: Dye-sensitized solar cell, indoor application, sensitizers, photoanode, electrolyte, Counter electrode

\begin{tabular}{ll} 
& \multicolumn{1}{c}{ Abbreviations } \\
DSSC & Dye-sensitized solar cell \\
PV & Photovoltaic \\
CE & Counter electrode \\
PCE & Power conversion efficiency
\end{tabular}

\section{INTRODUCTION}

Humans have introduced more carbon dioxide into the environment than the earth's trees have been able to recycle since the industrial revolution, resulting in an increase in the global temperature. Photovoltaics (PVs) play a major role in energy harvesting and in realizing a low-carbon society. ${ }^{1-6}$ Alternative PVs are emerging alongside widely commercialized semiconductor technologies based on crystalline and thin-film silicon solar cells. ${ }^{7-14}$ In addition to thin-film structures such as CuIn$\mathrm{GaSe}_{2}{ }^{15,16}$ or $\mathrm{CdTe}{ }^{15}$ cells, perovskite solar cells have grown significantly in the last 5 years. ${ }^{17-21}$ The latter developed from dye sensitized solar cells (DSSCs), which have recently experienced substantial developments as part of the new environmentally sustainable PV technologies after the appearance of a publication in Nature by O'Regan and Grätzel in 1991. ${ }^{22-31}$

The organic material-based solar cell has three types, i.e., perovskite solar cells, polymer heterojunction solar cells, and DSSC. ${ }^{32}$ Among them perovskite solar cells give the highest efficiency; $23.3 \%$ efficiency was reached recently by a pervskite solar cell with single-junction layout. ${ }^{33}$ But the perovskite solar cell is less stable against oxygen and humidity, and the difficult production process still makes it very difficult to market. ${ }^{34,35}$ Polymer solar cells often require an intricate procedure for the manufacture of their cells and are less effective $(10 \%) .{ }^{36}$ The fabrication of DSSCs is much simpler and its related PCE has increased by $7 \%$ to $\sim 14 \% .{ }^{37-39}$ In all lighting conditions, DSSCs provide an effective power output, including fluorescent and LED lighting. In the conditions of diffused or dim sunlight they can also function well. In these lighting conditions, however, silicon-based solar cells are not as efficient and are not very competitive. $^{40}$

The solar cell industry can currently be split into large terrestrial power production panel facilities and smaller portable electronic modules. ${ }^{41}$ DSSCs may be used in both fields but within the second context they are more promising. They demonstrate excellent performance under indoor environment with an artificial light source compared to other solar cell technologies. ${ }^{42}$ This performance is essential for the development and manufacturing of indoor DSSCs different applications. For example, the Internet of Things (IoT) is attracting global scientific and technological attention nowadays since it underlines connections among wireless sensor nodes, consumer electronic devices, wearable devices, and smart meters. ${ }^{43,44}$ Although many small devices are connected with communication networks, there are major issues with charging such devices. ${ }^{44}$ For IoT devices, batteries may be used as power sources. However, the downside of the main batteries is that their lifespan is restricted within months to years. Such batteries need charging often for the secondary batteries. These issues do not occur in DSSCs, since the cells turn the room light directly into electricity without external power supply. In addition, the power needed for IoT devices is typically low and can be supplied under room light conditions by running the DSSCs. Hence, indoor DSSCs are regarded as promising IoT system power supply cells. ${ }^{45}$

DSSC efficiency depends on various variables, such as system design, a spectral response module, nature of the active material, light source power intensity and illuminance, irradiance, reflection, and temperature. Figure 1 provides a schematic diagram illustrating these variables. Researchers have made considerable efforts over the last few years to improve cost-effective, robust and effective DSSCs for indoor applications; however, these attempts are still inadequate and their physical and chemical properties must be refined in order to increase the performance of DSSC and commercialization. ${ }^{46,47}$ Additional study is needed to address certain crucial DSSC issues such as environmental durability, lifespan, large-scale processing, mechanical efficiency and spectral compatibility between the active DSSC material absorption range and the indoor irradiance range of light sources. In this regard, a thorough analysis of the production of DSSC for indoor applications will be very helpful in exploring the different issues that need careful attention. Thus, in this review we focused on different anode, sensitizer, electrolyte, and cathode materials used for indoor DSSC with the hope that this review will offer guidance to young researchers on the potential development of new materials with improved efficiency. This review aims to bind the work of different researchers together in order to increase the efficiency of the DSSC for indoor applications. The suggested modifications and 


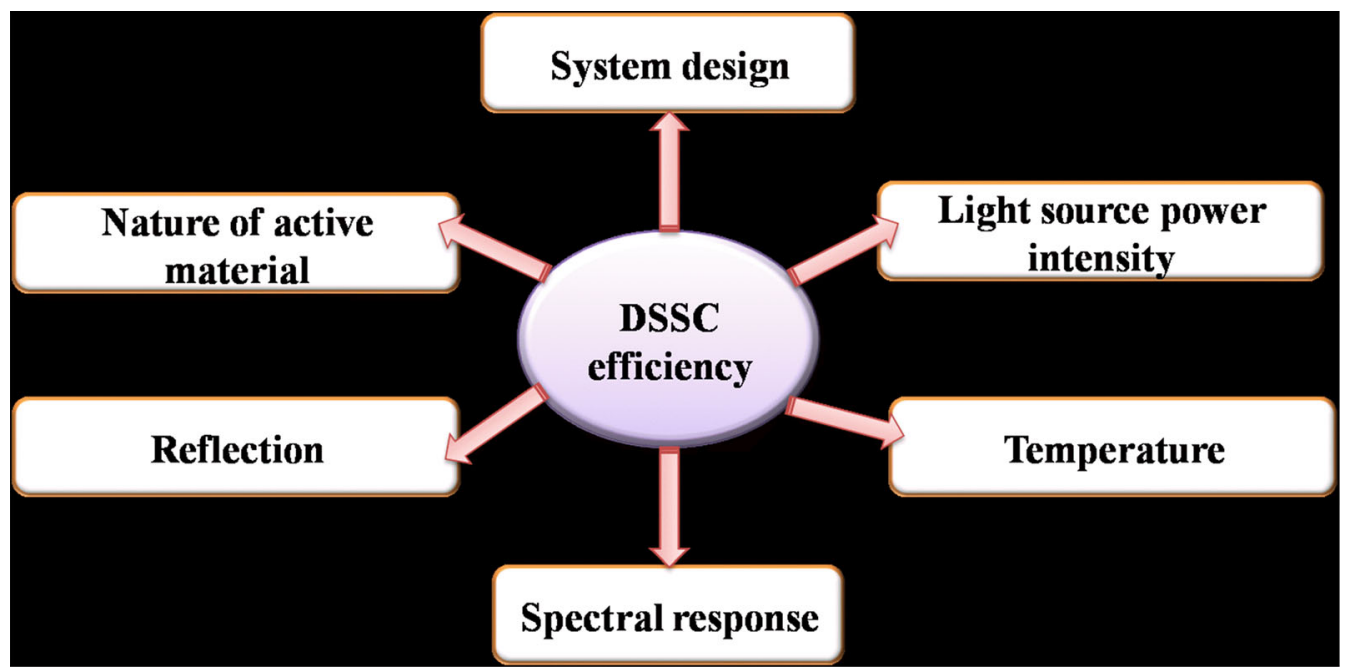

Fig. 1.. Illustration of the factors affecting efficiency of DSSC

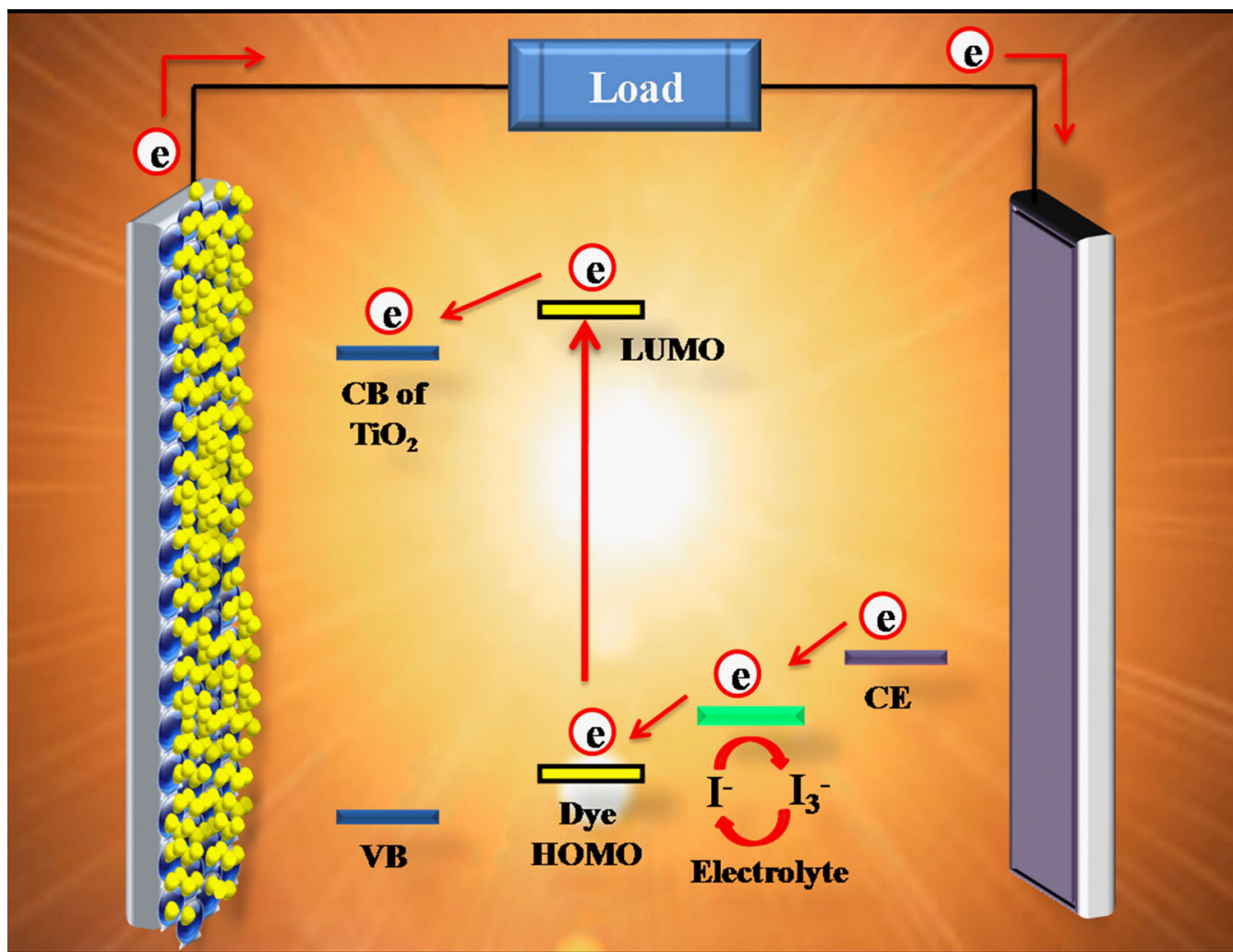

Fig. 2.. Working principle of DSSC

experiments are bifurcated appropriately, depending on the various DSSC components.

\section{ARCHITECTURE OF DSSC}

A standard DSSC consists of four essential components for initiating the conversion of solar energy to electrical energy. ${ }^{4-52}$ The components and their roles are: (i) photosensitizer for electron injection, (ii) photoanode for charge separation/conduction, (iii) redox electrolyte for dye regeneration and (iv) counter electrode (CE) for electron collection, as displayed in Fig 2. Visible-light transmission (400$700 \mathrm{~nm}$ ) of glass substrate coated with fluorinedoped tin oxide (FTO) or indium tin oxide (ITO) should be $>80 \%$ with low resistance $(<15$ to $40 \Omega /$ $\mathrm{sq} \mathrm{cm}$ ), allowing injection of electron and transmission. For superior conduction and transfer of charges, crystallization and annealing of titanium dioxide $\left(\mathrm{TiO}_{2}\right)$ film at $100-500{ }^{\circ} \mathrm{C}$ is necessary. 
Covalently bound monolayer sensitizer molecules to the $\mathrm{TiO}_{2}$ surface boost the absorption of photons and the production of e-h pairs. Regeneration of dye happens by solid (gel) or liquid electrolyte when sensitizers obtain their lost electrons from redox mediator reduction.

\section{WORKING OF DSSC}

The full operating process of DSSCs consists of the following phases. ${ }^{53-57}$

(i) Excitation of sensitizer (absorption of photonic energy): When sunlight strikes the DSSC, the sensitizer gets excited to a higher energy state [lowest unoccupied molecular orbital (LUMO)] from their ground state [highest occupied molecular orbital (HOMO)] and subsequently produces electrons and holes.

(ii) Injection of electron: The excited sensitizer is oxidized and an electron is inserted into the conduction band (CB) of the semiconductor $\left(\mathrm{TiO}_{2}\right)$, whereby electrons pass through the thin film of porous $\mathrm{TiO}_{2}$ to the transparent conducting oxide glass substrate to cathode from the anode through an external loop, creating current and completing cycles.

(iii) Regeneration of sensitizer: The redox pairs present in the electrolyte (e.g. iodide and triiodide $\left[\mathrm{I}^{-}=\mathrm{I}_{3}{ }^{-}\right]$redox pairs) donate the electron to oxidized-sensitizer, and thus it gets regenerated. (iv) Electrochemical reduction: In addition, iodide and the redox mediator in the electrolyte travel to the $\mathrm{CE}$ and are regenerated on the cathode by reducing tri-iodide.

In DSSCs, two recombinant mechanisms may be taken into account, where the oxidation of sensitizing molecules and redox electrolyte species occurs in two competing chemical reactions simultaneously. ${ }^{58}$ Within a microsecond timescale $\left(10^{-6} \mathrm{~s}\right)$, the recombination of photogenerated electrons are takes place with redox species $\left(\mathrm{I}_{3}^{-}\right)$or/and oxidized sensitizers. ${ }^{59,60}$

\section{DSSC PERFORMANCE PARAMETERS}

Since all forms of DSSCs are characterized by standard equipment for solar-cell testing, it is important to incorporate main parameters used for the experimental validation of DSSC systems.

An essential quantity reflecting a solar cell's total efficiency is the power conversion efficiency (PCE) $(\eta)$

$$
\eta=\frac{V_{O C} J_{S C} F F}{P_{i n}} \times 100 \%
$$

$V_{O C}$ is the open-circuit voltage that is in contrast with the Fermi level of $\mathrm{TiO}_{2}$ and the redox potential of the electrolyte, ${ }^{42}$ and the incident-light power density is $P_{i n}$. $J_{S C}$ is the current width of the short circuit. FF is the fill factor that demonstrates the cell's inherent quality.

$$
F F=\frac{V_{\max } J_{\max }}{V_{O C} J_{S C}}
$$

where $V_{\max }$ and $J_{\max }$ correspond to voltage $(V)$ and current density $(J)$ values that maximize their product.

\section{RECENT DEVELOPMENT IN THE PHOTOANODE MATERIALS}

Semiconducting metal oxides with a wide band gap were deposited on FTO or ITO and were used as photoanode materials. The recent advancement in materials used for the photoanode is presented here.

A thin layer of $\mathrm{Nb}_{2} \mathrm{O}_{5}$ was coated onto the FTO glass utilizing a simple dip-coating process as an effective DSSC photoanode substrate material and its blocking effect on the recombination of charges under different illuminance was analysed by Chen et al. ${ }^{61}$. The results showed that the blocking effect by $\mathrm{Nb}_{2} \mathrm{O}_{5}$ is strongly dependent on the illuminance intensity, whereas at strong (one sun, $>100,000$ lux) illumination, the blocking effect of $\mathrm{Nb}_{2} \mathrm{O}_{5}$ is negligible, since the suppressed reverse charge flux allows no significant impact to high-level injection of photo-excited charges. In comparison, the blocking effect plays an essential role in increasing the performance as the photon-injected charge flux decreases dramatically at low-intensity illumination (300-6000 lux). Moreover the device showed a significant improvement in $\mathrm{FF}$ which successfully increased the PCE of DSSCs by $10 \%$ to $53 \%$ under low-intensity illumination from 6000 to 300 lux. Furthermore, the same research group ${ }^{62}$ deposited $\mathrm{Nb}_{2} \mathrm{O}_{5}$ above the $\mathrm{TiO}_{2}$ layer via dip-coating with different cycles ( 1,3 and 5 ). Results revealed that under one sun illumination, the device without $\mathrm{Nb}_{2} \mathrm{O}_{5}$ displayed an efficiency of $5.26 \%$ and the device with $\mathrm{Nb}_{2} \mathrm{O}_{5}$ (1 dipping cycle) displayed an efficiency of $5.94 \%$. Also, the device with $\mathrm{Nb}_{2} \mathrm{O}_{5}$ showed the highest efficiency of $17.40 \%$ under 6000 lux illumination, whereas the device without $\mathrm{Nb}_{2} \mathrm{O}_{5}$ displayed $15.53 \%$ efficiency under the same condition. It suggests that the thin film of $\mathrm{Nb}_{2} \mathrm{O}_{5}$ serves as a shielding film which efficiently inhibits the recombination of charges on the photoanode.

Chou et al. ${ }^{63}$ prepared a photoanode containing a composite of $\mathrm{TiO}_{2}$-reduced graphene oxide-indium gallium zinc oxide (TGI), which was synthesized using a hydrothermal process, spin coating and sputtering. Their study revealed that the device with TGI photoanode displayed an efficiency of $5.66 \%$ and the device with $\mathrm{TiO}_{2}$ displayed a PCE of $3.46 \%$ under $100 \mathrm{~mW} \mathrm{~cm} \mathrm{~cm}^{-2}$ illumination, whereas 
under $0.63 \mathrm{~mW} \mathrm{~cm} \mathrm{~cm}^{-2}$ illumination, both devices showed an increase in efficiency of $7.97 \%$ (TGI) and $4.70 \%\left(\mathrm{TiO}_{2}\right)$. The highest efficiency of TGI based device was due to the reduction in dark reaction. RGO's intense electrical mobility speeds up photogenerated electrons from the $\mathrm{TiO}_{2}$ conductive band to the FTO conductive band prior to recombination. In fact, the IGZO creates a shield to prevent the recombination of photogenerated electrons and $\mathrm{I}_{3}^{-}$.

In one more work, Hora et al. ${ }^{64}$ optimized the $\mathrm{TiO}_{2}$ photoanode for DSSC's indoor application. In this work, photoanode mesoporous layers were modified in thickness and light-scattering capacity to optimize light harvesting and decrease recombination loss. A $\mathrm{TiO}_{2}$ blocking layer and the $\mathrm{TiO}_{2}$ mesoporous layer treated with titanium tetrachloride $\left(\mathrm{TiCl}_{4}\right)$ decreased the re-combination of the electron back with electrolyte. After the optimization, the device displayed $9.84 \%$ efficiency under simulated solar light and also it displayed $28.7 \%$ efficiency under indoor light condition.

For the activity of cobalt-mediated DSSCs under indoor light illuminations, compact blocking layer with powerful blocking feature is eminently necessary. The DSSCs use conventional $\mathrm{TiCl}_{4}$-derived blocking layers functions effectively under normal sunlight while the extreme transfer of electrons from the FTO to the electrolyte under room light condition limits the efficiency of these devices. To overcome this effect, Liu et al. ${ }^{65}$ employed spray pyrolysis to prepare compact blocking layers. Their experimental finding shows that the compact blocking layer will prevent electron leakage across a broad spectrum of intensities, allowing the DSSCs to function efficiently in low-light conditions. Also, they anticipated that other methods of thin film production will perform a specific blocking role in addition to the spray pyrolysis. The device with compact blocking layer displayed highest efficiencies of $15.26 \%, 14.59 \%$, and $15.12 \%$ compared to $\mathrm{TiCl}_{4}$ blocking layer based DSSC $(8.56 \%, 7.46 \%$, and 6.19\%) under 1001 lux, 601 lux, and 251 lux illumination, respectively.

Nien et al. ${ }^{66}$ prepared $\mathrm{TiO}_{2}$ nanofibers containing silver (Ag) NPs (TNSN) by employing the sol-gel method for photoanode application in DSSC. They prepared TNSN in two ways, firstly, they mixed TNSN with pristine $\mathrm{TiO}_{2}$ and next, they initially coated pristine $\mathrm{TiO}_{2}$ after which they coated TNSN above the $\mathrm{TiO}_{2}$ layer $\left(\mathrm{TiO}_{2} / \mathrm{TNSN}\right)$. Among these two photoanodes, the $\mathrm{TiO}_{2} / \mathrm{TNSN}$ based device displayed the highest PCE of 5.13\% under 100 $\mathrm{mW} \mathrm{\textrm {cm } ^ { - 2 }}$ illumination. This was attributed to the inhibition of electron recombination by introducing the TNSN and the effective use of light radiation. Because of Ag's excellent conductivity, the electrons were transferred easily and the recombination of electrons was minimized. In comparison, the DSSC based on $\mathrm{TiO}_{2} / \mathrm{TNSN}$ displayed an increase in efficiency of $6.23 \%$ under $30 \mathrm{~mW} \mathrm{~cm}^{-2}$; conversely, its PCE reduced to $5.31 \%$ as light dropped to $10 \mathrm{~mW}$ $\mathrm{cm}^{-2}$ intensity.

A bifacial DSSC with improved light scattering was fabricated by Sasidharan et al. ${ }^{67}$ by using templated $\mathrm{TiO}_{2}$ surfaces formed by fugitive $\mathrm{ZnO}$ microflower inclusions. The optimized device showed highest efficiency of $6.82 \%$ and $4.71 \%$ under one sun condition front and back side illuminations, respectively. Further, it showed the highest efficiency of $11.8 \%$ under 1000 lux CFL illumination compared to bare $\mathrm{TiO}_{2}(6.39 \%)$.

\section{RECENT DEVELOPMENTS IN THE ELECTROLYTE MATERIALS}

Typically, DSSCs with novel sensitizers and iodide electrolyte are used in room light applications. ${ }^{68-71}$ The optimal conditions used for these devices vary from those which work under AM 1.5 solar light conditions. Unlike AM 1.5 solar light conditions, under indoor light conditions only a few electrons are excited. These electrons are easily recombined with the redox pairs, which has a serious effect on the cell $V_{O C}{ }^{72}$ Similarly, under room light illumination, the formation of excited holes reduce, under which a limited volume of iodide is adequate to minimize the number of holes created. Because of the amount of iodine in the electrolyte, the light intensity is often influenced. To overcome this problem, Venkatesan et al. ${ }^{73}$ prepared an electrolyte using a cobalt redox pair and 3methoxypropionitrile solvent. Also, they regulated the DSSC components, photoanode, $\mathrm{CE}$, and electrolytes to get the finest device performance. The experimental findings reveal that the DSSC with a photoanode with a $\mathrm{TiO}_{2}$ layer that is $10 \mu \mathrm{m}$ thick (4 $\mu \mathrm{m}$ scattering layer and $6 \mu \mathrm{m}$ main layer), Y123 dye, an electrolyte consisting of a Co (II / III) ratio of 0.11/0.025 M, 1.2 M 4-tert-butylpyridine, a CE with a Pt layer thickness of $0.16 \mathrm{~nm}$ are the ideal conditions for obtaining a high PCE. This device displayed the highest efficiency of $24.52 \%, 23.48 \%$, and $22.66 \%$ under T5 light illumination of 999.6 lux, 607.8 lux, and 201.8 lux. At a $\mathrm{TiO}_{2}$ layer of $8 \mu \mathrm{m}$ thickness, the bifacial cell demonstrated an optimum PCE of $17.31 \%$ under rear illumination and $20.65 \%$ under front illumination. Moreover, these devices were also long-lasting and were able to maintain $100 \%$ of their initial performance after a 1000-h examination at $35^{\circ} \mathrm{C}$.

To date, the efficiency of liquid-state devices under ambient light conditions has only been recorded by minimal studies. The key concern of this DSSC class is electrolyte leakage and organic solvent evaporation. This disadvantage greatly affects the DSSCs' long-term performance, which can limit their IoT applications and other applications. In comparison, good efficiency was only obtained in laboratory devices using the injection technology for fabrication. In reality, this approach is not ideal for large-scale cells. The 
printable electrolytes (PEs) can solve these two issues, which can be coated using a printing technique on a photoelectrode. ${ }^{74-77}$ This method can be used in large-scale DSSC development due to good penetration of the extremely viscous polymer gel electrolytes and roll-to-roll coating processes. Venkatesan et al. ${ }^{78}$ have developed printable electrolytes for this reason, using 3-methoxypropionitrile comprising $\mathrm{TiO}_{2}$ nanofillers, polyethylene oxide (PEO)/polyvinylidene fluoride (PVDF) gelator, and an iodide/tri-iodide redox mediator. They observed that modifying the formulations of the polymers did not significantly affect the PCE of the DSSCs. The device efficiency relied mainly on the $\mathrm{TiO}_{2}$ thickness in the photoelectrode and the concentration of the iodine in the electrolyte. The diffusivity of ions reduced and the conductivity of electrolytes improved with an increased concentration of iodine in the electrolyte. Nevertheless, the DSSC's efficiency was not linked to the electrolytes ion conductivity and diffusivity characteristics, but instead to the photoelectrode/electrolyte interface charge transfer resistance and the DSSC's IPCE. Furthermore, the optimized device having N719 dye displayed the highest efficiency of $20.67 \%$ and $15.39 \%$ under 600 lux and 200 lux illumination, respectively. In addition, high efficiencies of $12.8 \%$ and $11.2 \%$ were achieved by the sub-module cells using Z907 and N719 sensitizers, respectively, under 200 lux irradiation. The long-term stability analysis reveals that after $1000 \mathrm{~h}$ of under 200 lux irradiation, the production of DSSC would maintain its initial performance by $97 \%$.

In one more work, the same research group ${ }^{45}$ prepared cobalt based gel polymer electrolyte (GPE) containing poly(vinylidene fluoride-co-hexafluoropropylene) and different metal oxide nanofillers for DSSC indoor application. Among the other GPE, zinc oxide nanofillers containing GPE displayed the highest efficiency of $20.11 \%$ under 200 lux of T5 fluorescent light which is higher than the corresponding liquid-state DSSC. Where, zinc oxide nanofillers reduce the diffusivity of ions and the electrolytes conductivity. However, the efficiency of the device was not affected by this, but were highly reliant on the DSSC capacitance and charge transfer resistance at the photoelectrode/electrolyte interface, whereas the reduction in capacitance and the rise in charge transfer resistance at the photoelectrode/electrolyte interface in the zinc oxide nanofillers's presence contributed to the DSSC's high $V_{O C}$. Furthermore, the iodine or cobalt redox couple containing PEO and poly(methyl methacrylate) (PMMA) PEs were prepared by the same research group. ${ }^{79}$ Moreover, $\mathrm{PEO} \mathrm{PE}$ with a cobalt redox mediator has shown to be more ideal for assembly of high-performance room light DSSCs (21.06\%) than iodide PEO/PMMA PE. The optimum PEO PE had less ion conductivity and diffusivity than the respective liquid electrolyte. The efficiency of the DSSC with this PE was, however, close to that of the device utilizing liquid electrolyte under the illumination of 200 lux T5 radiation. Also, this efficiency was considerably superior to the DSSC efficiency using iodide PEs. The cobalt PE submodulated cell displayed a high efficiency of $12.60 \%$, whereas the bifacial DSSCs utilizing the 9 wt\% PEO demonstrated a performance of $17.60 \%$ and $14.58 \%$ under the 200 lux conditions from front and back illumination, respectively. These PE-based cells showed greater stability than the liquid electrolyte-based cells at $35^{\circ} \mathrm{C}$.

Double-layered printable electrolytes were prepared by Liu et al. ${ }^{80}$ using PVDF and PEO blend having zinc oxide. The optimized device showed the highest efficiency of $8.50 \%, 15.7 \%$, and $15.9 \%$ under AM 1.5G, indoor fluorescent lighting 200 lux and 1000 lux conditions, respectively.

\section{RECENT DEVELOPMENTS IN THE CE MATERIALS}

The CE, a major component of a DSSC, must have a high conductivity to transport electrons flowing via an external circuit and an excellent catalytic ability to reduce $\mathrm{I}_{3}{ }^{-81-84} \mathrm{Pt}$ is the most frequently used catalyst on the CE in DSSCs because of its high stability, high conductivity and high electrocatalytic activity towards redox reaction. But the $\mathrm{Pt}$ CE's high cost and energy-consuming manufacturing process restricts its applicability. To replace Ptbased $\mathrm{CE}$, a $\mathrm{CoSe}_{2} / \mathrm{CoSeO}_{3}$ hierarchical urchin-like structured $\left(\mathrm{CoSe}_{2} / \mathrm{CoSeO}_{3}\right.$-UL) $\mathrm{CE}$ material was prepared by Huang et al. ${ }^{85}$ via a one-step hydrothermal process. For comparison, they also prepared $\mathrm{CoSe}_{2} / \mathrm{CoSeO}_{3}$ nanoparticles and platinum (Pt)based CEs. $\mathrm{CoSe}_{2} / \mathrm{CoSeO}_{3}$-UL comprises hexagonal prisms and nanoparticles which provide a onedimensional charge transport route and a large surface area for catalytic reactions, respectively. Under 1 sun condition, a $\mathrm{CoSe}_{2} / \mathrm{CoSeO}_{3}$-UL CE based device displayed the highest efficiency of 9.29\% compared to $\mathrm{Pt}(8.33 \%)$ and $\mathrm{CoSe}_{2} / \mathrm{CoSeO}_{3}$ NP (8.81\%) CE based devices. Also, under dim light conditions, $\mathrm{CoSe}_{2} / \mathrm{CoSeO}_{3}$-UL $\mathrm{CE}$ based device showed efficiencies of $16 \%$ (4,800 lux), $18.24 \%$ $(6,000$ lux $)$, and $19.88 \%$ (7,000 lux). Further, the same research group ${ }^{86}$ also prepared pristine carbon aerogels (CAs) based CE for replacing Pt CE, whereas the CAs were prepared via sol-gel method by regulating the molar ratios of resorcinol (R)/sodium carbonate (C) and resorcinol (R)/formaldehyde (F). They found that highest specific surface area of the CE reached $724 \mathrm{~m}^{2} \mathrm{~g}^{-1}$ with 377 and 0.76 molar ratios of $\mathrm{R} / \mathrm{C}$ and $\mathrm{R} / \mathrm{F}$ and this $\mathrm{CE}$ based device displayed the highest efficiency of $9.08 \%$ under 1 sun condition. Also, this device achieved an efficiency of $9.16 \%$ and $20.1 \%$ under 0.5 sun and T5 lamp with 7000 lux conditions, respectively. In addition, $\mathrm{CoSe}_{2} / \mathrm{CoSeO}_{3}-\mathrm{UL}$ 
and CAs have tremendous potential to substitute Pt in DSSCs as a highly effective electro-catalyst.

\section{RECENT DEVELOPMENTS IN THE SENSITIZERS}

Among the dyes developed (metal-free organic dyes, ruthenium, porphyrin, etc.), metal-free organic sensitizers have been studied extensively due to the benefits of low synthetic cost, versatile molecular design, environmental friendly and potentially higher extinction coefficients. ${ }^{87,88}$ Recently, ample work has been conducted to make all feasible improvements in the sensitizers for indoor DSSC applications. Few of those are presented here. The chemical structures of the dyes are presented in a separate section below and the corresponding PV parameters of DSSCs under room light conditions are presented in Table I.

Chen et al. ${ }^{89}$ synthesized a sequence of dyes (1-6) for DSSCs and tested them under standard AM 1.5 and indoor light illuminations. Under AM 1.5 conditions, the highest efficiency was obtained for dye 4 based device (5.02\%). While the highest efficiency values obtained under the T5 and LED lamps were $13.43 \%$ (dye 4) and $12.21 \%$ (dye 6), respectively. They explored the connection between the dye's molecular structure and their subsequent efficiency and they found the following approaches to produce the optimal sensitizers for indoor light condition. (i) It is desirable to increase the amount of alkyl chains on the sensitizers to lift the $V_{O C}$ of the device. (ii) The dye's absorption range would also align with the indoor light emission spectra. The emission spectrum of indoor light does not cover the near-infrared region (NIR) region $(>700 \mathrm{~nm})$ as opposed to the solar spectrum. For this case, the optimal dye under indoor lighting does not require either a long conjugation framework or a strong dipole, which dramatically lowers the synthetic costs of the dyes.

Furthermore, four new dyes (7-10) with two bis(alkoxy)phenyl substituent containing a benzo[3,4-b]pyrazine (BP) or a thieno[3,4-b]pyrazines (TP) agent as auxiliary acceptor were reported by Desta et al. ${ }^{90}$. They found that the addition of the 3,4-dihexyloxyphenyl moiety at the TP and BP's 2and 3-sites increases its solubility in organic solvents and helps inhibit dark current in the device. The devices produced from the two BP dyes ( 8 and 10) with a chenodeoxycholic acid displayed efficiency of $8.39 \%$ and $9.03 \%$ respectively, under 1 sun illumination. Also, 10 exhibited a PCE of $27.17 \%$ and $18.95 \%$ under 6,000 lux and 300 lux luminance, respectively, under dim light conditions.

For indoor and outdoor dye-sensitized studies of solar cells, three novel organic dyes based on anthracene, denoted as $\mathbf{1 1}, \mathbf{1 2}$, and 13 were synthesized by Tsai et al. ${ }^{91}$. Further, they prepared flexible and rigid modules, as well as small cells, and their PV efficiencies were evaluated. The $\mathbf{1 1}$ unit gives rise to a black colour and exhibits an excellent PV efficiency, because of the panchromatic absorption of visible light. Under 1000 lux fluorescent light of T5, the 11/R26 module performs better than the Z907 counterpart with an efficiency of $11.94 \%$. Furthermore the same research group ${ }^{92}$ synthesized five more dyes labeled 14, 15, 16, 17, and 18 . 15, 14, and 11, (or 18, 17 and 16) chemical structures vary in their anchoring groups, i.e., hydroxamic acid, isophthalic acid, and carboxylic acid, respectively. Additionally, an ethynyl bridge is positioned between the anchoring groups and the benzothiodiazoyl moiety for $\mathbf{1 6}, \mathbf{1 7}$, and $\mathbf{1 8}$. The small cell with $\mathbf{1 6}$ outperforms others and the counterpart (dye 11) under 1 sun irradiation. Further, under 1000 lux of indoor light T5, the $\mathbf{1 6}$ based device displayed PCE of $13.48 \%$ which surpasses the PCE of the $\mathbf{1 1}$ based device (11.94\%).

Chou et al. ${ }^{93}$ synthesized perylene based dyes (19-23) with $\mathrm{N}, \mathrm{N}$-diarylamine and arylcarboxylic acid as the donor and acceptor units, respectively. The 23 dye displayed the highest efficiency of $6.16 \%$ using liquid iodide-based electrolyte under the illumination of AM $1.5 \mathrm{G}$ simulated sunlight. This dye based device also showed a good efficiency of $15.79 \%$ under 6000 lux light intensity (T5). Ironically, under the same condition, $\mathbf{1 9}$ with a simple molecular structure showed an efficiency of $15.01 \%$.

Freitag et al. $^{42}$ fabricated a device with two sensitizers (24 and 25) with $\mathrm{Cu}(\mathrm{II} / \mathrm{I})($ tmby) redox couple (tmby $=4,4^{\prime}, 6,6^{\prime}$-tetramethyl-2,2'-bipyridine). The optimized device displayed a $\mathrm{V}_{\text {OC }}$ over 1 $\mathrm{V}$ and high efficiency of $11.3 \%$. Also, this device reached an external quantum efficiency for photocurrent generation that surpassed $90 \%$ over the entire visible domain from 400 to $650 \mathrm{~nm}$ and achieved power outputs of $15.6 \mathrm{~mW} \mathrm{~cm}$ (200 lux) and $88.5 \mathrm{~mW} \mathrm{~cm}^{-2}$ (1000 lux). Under 1000 lux condition, the optimized device showed the highest PCE of $28.9 \%$.

A series of dyes (26-31) with spiro[fluorene-9,9'phenanthren]-1"-one as an auxiliary acceptor were 
Table I. PV parameters of different dyes based DSSC under room light conditions.

\begin{tabular}{|c|c|c|c|c|c|c|c|}
\hline Dyes & PCE (\%) & $\mathbf{F F}$ & $\mathbf{V}_{\text {OC }}(\mathrm{V})$ & $J_{\mathrm{SC}}\left(\mathbf{m A} / \mathrm{cm}^{2}\right)$ & Light source & Light intensity (lux) & References \\
\hline \multirow[t]{2}{*}{1} & 6.42 & 0.67 & 0.5 & 0.038 & LED & 600 & 89 \\
\hline & 7.8 & 0.67 & 0.49 & 0.044 & $\mathrm{~T} 5$ & 600 & \\
\hline \multirow[t]{2}{*}{2} & 11.71 & 0.73 & 0.57 & 0.056 & LED & 600 & \\
\hline & 12.73 & 0.71 & 0.55 & 0.06 & $\mathrm{~T} 5$ & 600 & \\
\hline \multirow[t]{2}{*}{3} & 6.56 & 0.69 & 0.53 & 0.036 & LED & 600 & \\
\hline & 9.99 & 0.71 & 0.55 & 0.047 & $\mathrm{~T} 5$ & 600 & \\
\hline \multirow[t]{2}{*}{4} & 11.49 & 0.7 & 0.58 & 0.056 & LED & 600 & \\
\hline & 13.43 & 0.7 & 0.6 & 0.058 & $\mathrm{~T} 5$ & 600 & \\
\hline \multirow[t]{2}{*}{5} & 10.76 & 0.73 & 0.59 & 0.050 & LED & 600 & \\
\hline & 12 & 0.71 & 0.6 & 0.053 & $\mathrm{~T} 5$ & 600 & \\
\hline \multirow[t]{2}{*}{6} & 12.21 & 0.71 & 0.56 & 0.061 & LED & 600 & \\
\hline & 12.74 & 0.7 & 0.5 & 0.062 & $\mathrm{~T} 5$ & 600 & \\
\hline \multirow[t]{4}{*}{ 7+CDCA } & 6.39 & 0.75 & 0.49 & 0.015 & T5 & 300 & 90 \\
\hline & 6.67 & 0.75 & 0.51 & 0.029 & T5 & 600 & \\
\hline & 6.81 & 0.76 & 0.53 & 0.044 & T5 & 900 & \\
\hline & 8.62 & 0.76 & 0.58 & 0.315 & T5 & 6000 & \\
\hline \multirow[t]{4}{*}{ 8+CDCA } & 15.1 & 0.77 & 0.54 & 0.033 & T5 & 300 & \\
\hline & 16.49 & 0.77 & 0.68 & 0.067 & T5 & 600 & \\
\hline & 17.38 & 0.78 & 0.58 & 0.104 & T5 & 900 & \\
\hline & 23.17 & 0.79 & 0.65 & 0.762 & T5 & 6000 & \\
\hline \multirow[t]{4}{*}{ 9+CDCA } & 12.08 & 0.76 & 0.54 & 0.26 & T5 & 300 & \\
\hline & 12.79 & 0.77 & 0.56 & 0.53 & T5 & 600 & \\
\hline & 13.24 & 0.77 & 0.57 & 0.8 & T5 & 900 & \\
\hline & 16.86 & 0.77 & 0.63 & 0.562 & T5 & 6000 & \\
\hline \multirow[t]{4}{*}{$10+\mathrm{CDCA}$} & 18.95 & 0.75 & 0.57 & 0.04 & T5 & 300 & \\
\hline & 20.16 & 0.76 & 0.59 & 0.081 & T5 & 600 & \\
\hline & 21.1 & 0.76 & 0.61 & 0.124 & T5 & 900 & \\
\hline & 27.17 & 0.76 & 0.67 & 0.913 & T5 & 6000 & \\
\hline \multirow[t]{6}{*}{11} & 9.08 & 0.64 & 0.90 & 0.010 & T5 & 200 & 91 \\
\hline & 11.17 & 0.65 & 1 & 0.034 & T5 & 600 & \\
\hline & 11.94 & 0.64 & 1.05 & 0.061 & $\mathrm{~T} 5$ & 1000 & \\
\hline & 9.68 & 0.64 & 0.9 & 0.010 & LED & 200 & \\
\hline & 10.95 & 0.65 & 0.99 & 0.031 & LED & 600 & \\
\hline & 11.26 & 0.64 & 1.03 & 0.529 & LED & 1000 & \\
\hline \multirow[t]{6}{*}{16} & 11.77 & 0.68 & 0.43 & 0.023 & $\mathrm{~T} 5$ & 200 & 92 \\
\hline & 13.30 & 0.70 & 0.47 & 0.066 & T5 & 600 & \\
\hline & 13.48 & 0.75 & 0.49 & 0.116 & T5 & 1000 & \\
\hline & 9.13 & 0.66 & 0.42 & 0.021 & LED & 200 & \\
\hline & 11.29 & 0.7 & 0.47 & 0.064 & LED & 600 & \\
\hline & 12.82 & 0.75 & 0.49 & 0.114 & LED & 1000 & \\
\hline \multirow{16}{*}{$19+\mathrm{CDCA}$} & 9.15 & 0.69 & 0.49 & 0.027 & T5 & 300 & 93 \\
\hline & 10.37 & 0.72 & 0.50 & 0.056 & T5 & 600 & \\
\hline & 11.27 & 0.73 & 0.51 & 0.085 & T5 & 900 & \\
\hline & 12.14 & 0.73 & 0.53 & 0.117 & T5 & 1200 & \\
\hline & 12.94 & 0.74 & 0.55 & 0.221 & T5 & 2400 & \\
\hline & 13.49 & 0.74 & 0.57 & 0.334 & T5 & 3600 & \\
\hline & 14.19 & 0.74 & 0.58 & 0.459 & T5 & 4800 & \\
\hline & 15.01 & 0.74 & 0.59 & 0.594 & T5 & 6000 & \\
\hline & 8.35 & 0.70 & 0.46 & 0.026 & LED & 350 & \\
\hline & 9.29 & 0.72 & 0.49 & 0.048 & LED & 600 & \\
\hline & 10.47 & 0.72 & 0.51 & 0.076 & LED & 900 & \\
\hline & 10.74 & 0.73 & 0.52 & 0.102 & LED & 1200 & \\
\hline & 12.13 & 0.74 & 0.56 & 0.213 & LED & 2400 & \\
\hline & 12.56 & 0.74 & 0.57 & 0.321 & LED & 3600 & \\
\hline & 12.62 & 0.74 & 0.58 & 0.427 & LED & 4800 & \\
\hline & 13.05 & 0.74 & 0.59 & 0.540 & LED & 6000 & \\
\hline
\end{tabular}


Table I. continued

\begin{tabular}{|c|c|c|c|c|c|c|c|}
\hline Dyes & PCE (\%) & $\mathbf{F F}$ & $\mathbf{V}_{\mathbf{O C}}(\mathrm{V})$ & $\begin{array}{c}\mathbf{J}_{\mathrm{SC}}(\mathbf{m} \mathbf{A} / \\
\left.\mathbf{c m}^{\mathbf{2}}\right)\end{array}$ & Light source & $\begin{array}{c}\text { Light intensity } \\
(\text { lux })\end{array}$ & References \\
\hline \multirow[t]{16}{*}{$23+\mathrm{CDCA}$} & 9.12 & 0.62 & 0.45 & 0.029 & T5 & 300 & 93 \\
\hline & 11.76 & 0.68 & 0.48 & 0.062 & T5 & 600 & \\
\hline & 12.24 & 0.70 & 0.49 & 0.093 & T5 & 900 & \\
\hline & 13.26 & 0.72 & 0.50 & 0.127 & T5 & 1200 & \\
\hline & 14.12 & 0.74 & 0.53 & 0.254 & T5 & 2400 & \\
\hline & 14.83 & 0.75 & 0.54 & 0.382 & T5 & 3600 & \\
\hline & 15.29 & 0.75 & 0.55 & 0.510 & T5 & 4800 & \\
\hline & 15.79 & 0.76 & 0.56 & 0.640 & T5 & 6000 & \\
\hline & 8.13 & 0.63 & 0.45 & 0.029 & LED & 350 & \\
\hline & 9.58 & 0.68 & 0.48 & 0.053 & LED & 600 & \\
\hline & 10.29 & 0.70 & 0.49 & 0.080 & LED & 900 & \\
\hline & 11.08 & 0.72 & 0.51 & 0.109 & LED & 1200 & \\
\hline & 12.11 & 0.74 & 0.53 & 0.222 & LED & 2400 & \\
\hline & 12.57 & 0.75 & 0.54 & 0.334 & LED & 3600 & \\
\hline & 13.03 & 0.76 & 0.56 & 0.443 & LED & 4800 & \\
\hline & 13.10 & 0.76 & 0.56 & 0.557 & LED & 6000 & \\
\hline \multirow[t]{2}{*}{$24: 25$} & 25.5 & 0.79 & 0.73 & 0.027 & Osram warm white 930 & 200 & 42 \\
\hline & 28.9 & 0.8 & 0.79 & 0.138 & & 1000 & \\
\hline \multirow[t]{2}{*}{26} & 16.64 & 0.70 & 0.55 & 0.078 & TL84 & 1000 & 94 \\
\hline & 17.94 & 0.71 & 0.59 & 0.195 & TL84 & 2500 & \\
\hline \multirow[t]{2}{*}{27} & 8.23 & 0.58 & 0.57 & 0.045 & TL84 & 1000 & \\
\hline & 9.02 & 0.61 & 0.61 & 0.110 & TL84 & 2500 & \\
\hline \multirow[t]{2}{*}{28} & 18.15 & 0.66 & 0.59 & 0.085 & TL84 & 1000 & \\
\hline & 20.83 & 0.68 & 0.63 & 0.222 & TL84 & 2500 & \\
\hline \multirow[t]{2}{*}{29} & 10.03 & 0.58 & 0.57 & 0.05 & TL84 & 1000 & \\
\hline & 11.76 & 0.59 & 0.63 & 0.146 & TL84 & 2500 & \\
\hline \multirow[t]{2}{*}{30} & 16.94 & 0.65 & 0.59 & 0.08 & TL84 & 1000 & \\
\hline & 19.74 & 0.69 & 0.65 & 0.201 & TL84 & 2500 & \\
\hline \multirow[t]{2}{*}{31} & 9.36 & 0.56 & 0.58 & 0.051 & TL84 & 1000 & \\
\hline & 11.74 & 0.60 & 0.65 & 0.137 & TL84 & 2500 & \\
\hline \multirow[t]{2}{*}{ N719:28 } & 24.45 & 0.66 & 0.569 & 0.12 & TL84 & 1000 & \\
\hline & 26.19 & 0.69 & 0.628 & 0.278 & TL84 & 2,500 & \\
\hline \multirow[t]{3}{*}{32} & 4.43 & 0.55 & 0.405 & 0.021 & TL84 & 600 & 26 \\
\hline & 7.50 & 0.83 & 0.415 & 0.040 & TL84 & 1000 & \\
\hline & 7.72 & 0.64 & 0.462 & 0.120 & TL84 & 2500 & \\
\hline \multirow[t]{3}{*}{33} & 6.71 & 0.58 & 0.459 & 0.030 & TL84 & 600 & \\
\hline & 8.52 & 0.71 & 0.459 & 0.048 & TL84 & 1000 & \\
\hline & 9.03 & 0.65 & 0.481 & 0.133 & TL84 & 2500 & \\
\hline \multirow[t]{3}{*}{34} & 7.35 & 0.60 & 0.427 & 0.031 & TL84 & 600 & \\
\hline & 9.64 & 0.62 & 0.436 & 0.065 & TL84 & 1000 & \\
\hline & 9.86 & 0.70 & 0.492 & 0.131 & TL84 & 2500 & \\
\hline \multirow[t]{3}{*}{35} & 10.16 & 0.61 & 0.417 & 0.044 & TL84 & 600 & \\
\hline & 11.07 & 0.58 & 0.444 & 0.078 & TL84 & 1000 & \\
\hline & 12.14 & 0.66 & 0.496 & 0.170 & TL84 & 2500 & \\
\hline \multirow[t]{3}{*}{36} & 12.38 & 0.55 & 0.480 & 0.052 & TL84 & 600 & \\
\hline & 18.99 & 0.67 & 0.550 & 0.095 & TL84 & 1000 & \\
\hline & 19.89 & 0.65 & 0.570 & 0.248 & TL84 & 2500 & \\
\hline \multirow[t]{3}{*}{37} & 24.37 & 0.64 & 0.555 & 0.075 & TL84 & 600 & \\
\hline & 27.58 & 0.7 & 0.570 & 0.128 & TL84 & 1000 & \\
\hline & 27.82 & 0.69 & 0.597 & 0.309 & TL84 & 2500 & \\
\hline \multirow[t]{3}{*}{$37+\mathrm{DCA}$} & 25.42 & 0.66 & 0.56 & 0.075 & TL84 & 600 & \\
\hline & 27.40 & 0.63 & 0.62 & 0.129 & TL84 & 1000 & \\
\hline & 28.95 & 0.70 & 0.62 & 0.303 & TL84 & 2500 & \\
\hline \multirow[t]{3}{*}{$37: 34$} & 27.76 & 0.67 & 0.537 & 0.084 & TL84 & 600 & \\
\hline & 28.74 & 0.64 & 0.598 & 0.137 & TL84 & 1000 & \\
\hline & 30.45 & 0.72 & 0.621 & 0.312 & TL84 & 2,500 & \\
\hline
\end{tabular}


Table I. continued

\begin{tabular}{|c|c|c|c|c|c|c|c|}
\hline Dyes & PCE (\%) & $\mathbf{F F}$ & $\mathbf{V}_{\text {OC }}(\mathrm{V})$ & $\mathbf{J}_{\mathrm{SC}}\left(\mathbf{m A} / \mathbf{c m}^{2}\right)$ & Light source & Light intensity (lux) & References \\
\hline \multirow[t]{3}{*}{39} & 15.6 & 0.51 & 0.487 & 0.038 & T5 & 187 & 95 \\
\hline & 17.2 & 0.57 & 0.523 & 0.111 & T5 & 597 & \\
\hline & 12.4 & 0.56 & 0.542 & 0.133 & $\mathrm{~T} 5$ & 1025 & \\
\hline \multirow[t]{3}{*}{40} & 18.7 & 0.55 & 0.495 & 0.041 & T5 & 187 & \\
\hline & 18.6 & 0.58 & 0.525 & 0.115 & $\mathrm{~T} 5$ & 597 & \\
\hline & 15.6 & 0.65 & 0.552 & 0.143 & $\mathrm{~T} 5$ & 1025 & \\
\hline \multirow[t]{3}{*}{41} & 22 & 0.58 & 0.501 & 0.045 & $\mathrm{~T} 5$ & 187 & \\
\hline & 23.6 & 0.61 & 0.528 & 0.138 & T5 & 597 & \\
\hline & 21.4 & 0.65 & 0.556 & 0.156 & $\mathrm{~T} 5$ & 1025 & \\
\hline \multirow[t]{3}{*}{$41+\mathrm{CDCA}$} & 27.5 & 0.59 & 0.526 & 0.053 & $\mathrm{~T} 5$ & 187 & \\
\hline & 26.8 & 0.62 & 0.568 & 0.144 & $\mathrm{~T} 5$ & 597 & \\
\hline & 25 & 0.63 & 0.576 & 0.224 & $\mathrm{~T} 5$ & 1025 & \\
\hline 42 & 19.46 & 0.76 & 0.585 & 0.827 & T5 & 6,000 & 96 \\
\hline 42:CW10 & 22.58 & 0.74 & 0.646 & 0.883 & T5 & 6,000 & \\
\hline $24: 43$ & 29.2 & 0.78 & 0.86 & 0.131 & LED & 1000 & 97 \\
\hline \multirow[t]{8}{*}{46} & 18.76 & 0.73 & 0.57 & 0.038 & T5 & 300 & 98 \\
\hline & 19.93 & 0.74 & 0.60 & 0.077 & T5 & 600 & \\
\hline & 21.85 & 0.74 & 0.62 & 0.121 & T5 & 900 & \\
\hline & 22.80 & 0.74 & 0.63 & 0.164 & T5 & 1200 & \\
\hline & 24.06 & 0.75 & 0.66 & 0.336 & $\mathrm{~T} 5$ & 2400 & \\
\hline & 25.03 & 0.75 & 0.67 & 0.511 & T5 & 3600 & \\
\hline & 25.68 & 0.75 & 0.68 & 0.669 & $\mathrm{~T} 5$ & 4800 & \\
\hline & 26.19 & 0.76 & 0.69 & 0.881 & T5 & 6000 & \\
\hline \multirow[t]{8}{*}{ 46+CDCA } & 21.4 & 0.76 & 0.62 & 0.039 & $\mathrm{~T} 5$ & 300 & \\
\hline & 21.8 & 0.77 & 0.64 & 0.078 & $\mathrm{~T} 5$ & 600 & \\
\hline & 23.6 & 0.77 & 0.66 & 0.121 & $\mathrm{~T} 5$ & 900 & \\
\hline & 24.4 & 0.77 & 0.67 & 0.164 & T5 & 1200 & \\
\hline & 25.6 & 0.78 & 0.69 & 0.333 & $\mathrm{~T} 5$ & 2400 & \\
\hline & 26.8 & 0.78 & 0.70 & 0.511 & T5 & 3600 & \\
\hline & 27.6 & 0.78 & 0.71 & 0.693 & T5 & 4800 & \\
\hline & 28.5 & 0.78 & 0.71 & 0.883 & T5 & 6000 & \\
\hline \multirow[t]{6}{*}{ 47+CDCA } & 2.48 & 0.68 & 0.50 & 0.061 & D65 & 1000 & 99 \\
\hline & 7.26 & 0.69 & 0.49 & 0.040 & CWF & 1000 & \\
\hline & 8.12 & 0.69 & 0.52 & 0.092 & CWF & 2200 & \\
\hline & 2.4 & 0.42 & 0.42 & 0.015 & TL84 & 600 & \\
\hline & 7.59 & 0.68 & 0.48 & 0.043 & TL84 & 1000 & \\
\hline & 8.78 & 0.69 & 0.53 & 0.111 & TL84 & 2500 & \\
\hline \multirow[t]{6}{*}{51} & 9.90 & 0.65 & 0.47 & 0.044 & T5 & 600 & 100 \\
\hline & 12.95 & 0.71 & 0.5 & 0.081 & T5 & 1200 & \\
\hline & 14.68 & 0.7 & 0.53 & 0.15 & T5 & 1800 & \\
\hline & 16.41 & 0.71 & 0.52 & 0.21 & $\mathrm{~T} 5$ & 2400 & \\
\hline & 17.02 & 0.7 & 0.55 & 0.24 & T5 & 3000 & \\
\hline & 20.98 & 0.71 & 0.60 & 0.62 & T5 & 6000 & \\
\hline
\end{tabular}


prepared by Huang et al.$^{94}$. The auxiliary moiety has the ability to reduce intermolecular accumulation and trap the $\mathrm{I}_{3}{ }^{-}$and $\mathrm{Li}^{+}$ions which prolongs the recombination of charges. Among the other dyes, the 28 based device (without deoxycholic acid) displayed the highest efficiency of $6.3 \%$ and $20.83 \%$ under AM 1.5 solar condition and TL85 (2500 lux) condition, respectively. Further, they measured the efficiency of DSSC with co-sensitization of 28 and N719 dyes. The optimized device displayed the highest efficiency of $8.55 \%$ under 1 sun illumination and also increased its efficiency to $24.45 \%$ and $26.19 \%$ at 1000 and 2500 lux illuminations, respectively. In addition, at 2500 lux condition, this device displayed a high stability that retained $84.5 \%$ after $336 \mathrm{~h}$.

Dyes (32-37) with quinoxaline or quinoxalinoid moieties were synthesized by Jiang et al. ${ }^{26}$ and studied their performance under room light and 1 sun conditions. Furthermore, the dyes with donor group at 2,3-positions of quinoxaline ( $\mathbf{3 4}$ and $\mathbf{3 5}$ ) displayed less PCEs compared to the donor unit at 5,8-positions (36 and 37). Under AM 1.5 solar light, 37 displayed the highest PCE of $6.96 \%$ when it was co-deposited with deoxycholic acid. They also found that the co-deposition of $\mathbf{3 4}$ and $\mathbf{3 7}$ enhances the coverage of the sensitizer on the $\mathrm{TiO}_{2}$ surface which promotes the efficiency of the device to $7.92 \%$. Under indoor illumination, also 37 with and without deoxycholic acid based devices displayed outstanding efficiencies. The $\mathbf{3 4}$ and $\mathbf{3 7}$ co-sensitized devices displayed the highest efficiency of $30.45 \%$ (2500 lux), under indoor light conditions.

$\mathrm{Li}$ et al. ${ }^{95}$ reported 38-41 dyes with tetraphenylethylene substituted phenothiazine (at N-position) core with different $\pi$-bridges (4-heptyl-4-hexyl-4Hcyclopenta[2,1-b:3,4-b']dithiophene, 4-hexyl-2,2'bithiophene, 3-hexylthiophene, or thiophene). These dyes built double-layered shelters to effectively prevent the oxidized electrolytes from reaching the $\mathrm{TiO}_{2}$ surface and also improved their light harvesting property. Among the other dye based devices, 41-based system displayed the highest PCE of 9.79\% under simulated AM 1.5 G condition, beating that of the N719 sensitized system (8.77\%). After the addition of the co-adsorbent chenodeoxycholic acid, the output improved to $10.87 \%$. In comparison, the 41-based DSSC demonstrated impressive efficiencies of $24.98 \%, 26.81 \%$, and $27.54 \%$ at 1,025 lux, 597 lux, and 187 lux, respectively, under dim light conditions.

An anthracene based dye (42) having benzoic acid acceptor group was synthesized by Reddy et al. ${ }^{96}$. The 42 dye based device showed an efficiency of
$5.75 \%$ under AM $1.5 \mathrm{G}$ condition, whereas under low light illumination of 6000 lux, the efficiency was increased to $20.95 \%$. In addition, they also cosensitized 42 with porphyrin dye which displayed efficiencies of 6.31 and $22.58 \%$ under AM $1.5 \mathrm{G}$ and 6000 lux illuminations respectively.

Tanaka et al. ${ }^{97}$ co-sensitized $\mathbf{4 3}$ dye with $\mathbf{2 4}$ dye to attain an efficient DSSC and used the $\mathrm{Cu}^{\mathrm{I} / \mathrm{II}}(\mathrm{tmby})_{2}$ electrolyte. Co-sensitized device displayed an efficiency of $9.1 \%$ at 1 sun and $9.4 \%$ at 0.1 sun conditions, superior or similar to the device utilizing 24 dye. Further, under artificial fluorescent lighting, the co-sensitized device displayed an efficiency of $29.2 \%$ at 1000 lux. They also mentioned that the cost of the sensitizer estimated to be decreased by ca. $30 \%$ if the $\mathbf{2 4}$ based device is replaced with the co-sensitized device without any loss of efficiency.

Tingare et al. ${ }^{98}$ synthesized dyes $(\mathbf{4 4 , 4 5}$, and 46) using easy, convergent and short synthetic routes, suitable for large-scale manufacturing. Their analysis revealed that the modification of alkyl to alkoxy chain and the insertion of electron deficient molecules into the 44, 45, and 46 dyes played an important role in increasing their performance. When PCE of 46 based DSSC was measured under 1 sun conditions, it displayed the highest efficiency of $8.08 \%$ compared to other dyes. In fact, sensitizer 46 reached a PCE of $20.72 \%$ and $28.56 \%$ while measuring 6000 lux under the commercial light emitting diode light source and T5 fluorescent lighting, respectively.

A series of sensitizers (47-50) containing Tshaped diarylamines as donors (phenyl-1-naphthylamine or diphenylamine), a dibenzofulvene connected to furanyl or thienyl as a $\pi$-spacer, and cyanoacrylic acid as anchoring units were synthesized by Chen et al. ${ }^{99}$. The optimized 47-based DSSC with co-adsorbent displayed the highest efficiency of $2.42 \%, \mathrm{FF}$ of 0.63 , a $\mathrm{V}_{\mathrm{OC}}$ of $0.63 \mathrm{~V}$, and $\mathrm{J}_{\mathrm{SC}}$ of $6.01 \mathrm{~mA} \mathrm{~cm}{ }^{-2}$ under AM 1.5 condition. The same experiment was also carried out with respect to multiple light intensities such as TL84, CWF, and D65. As a consequence, the 47-based device under 2500 lux intensity of TL84 showed the best efficiency of $8.78 \%$.

Sil et al. ${ }^{100}$ fabricated DSSC by using dye $\mathbf{5 1}$ as sensitizer, PVP-Pt on ITO glass or sputter-Pt on ITO/PET based counter electrode and altering the thickness of $\mathrm{TiO}_{2}$ layer. The optimized device having $8 \mu \mathrm{m}$ thick $\mathrm{TiO}_{2}$ layer, sensitized with $\mathbf{5 1}$ and PVP-Pt on ITO counter electrode showed the highest efficiency of $20.98 \%$ under 6000 lux illumination. At the same condition the efficiency of $19.69 \%$ was exhibited by the N719 dye sensitized device. 


\section{Chemical Structures of the Dyes Used}

\section{for Room Light DSSCs}
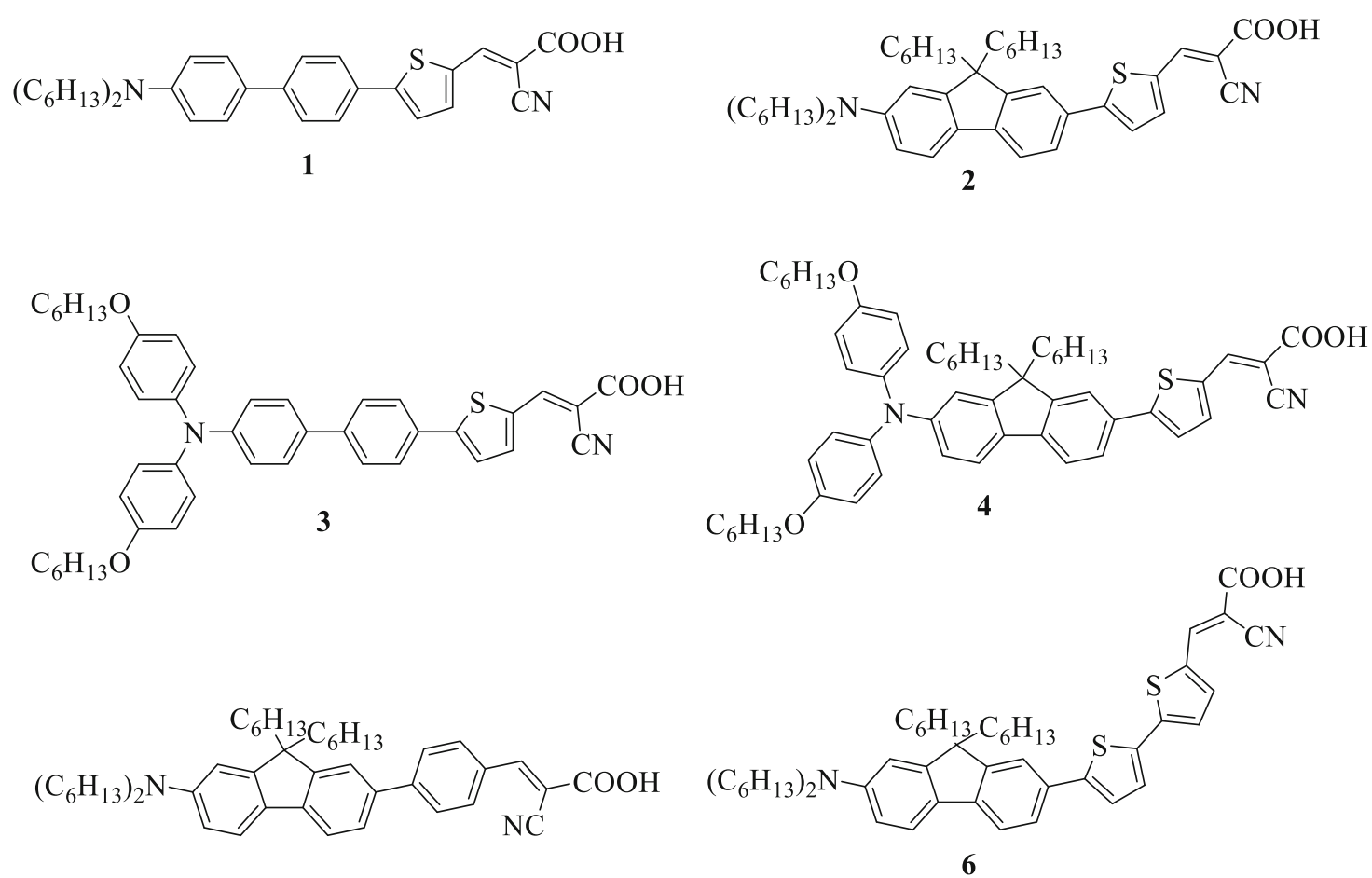

5
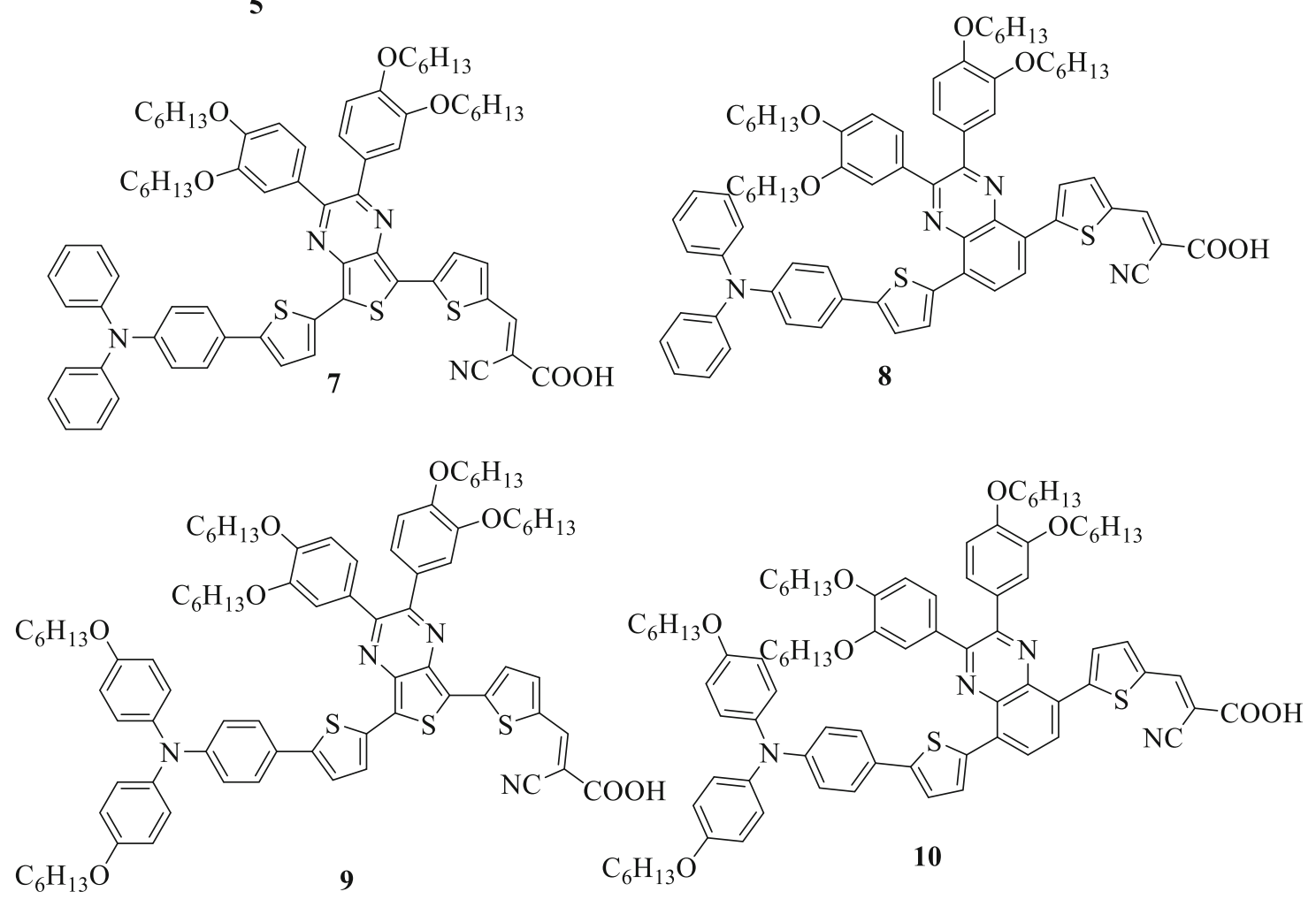

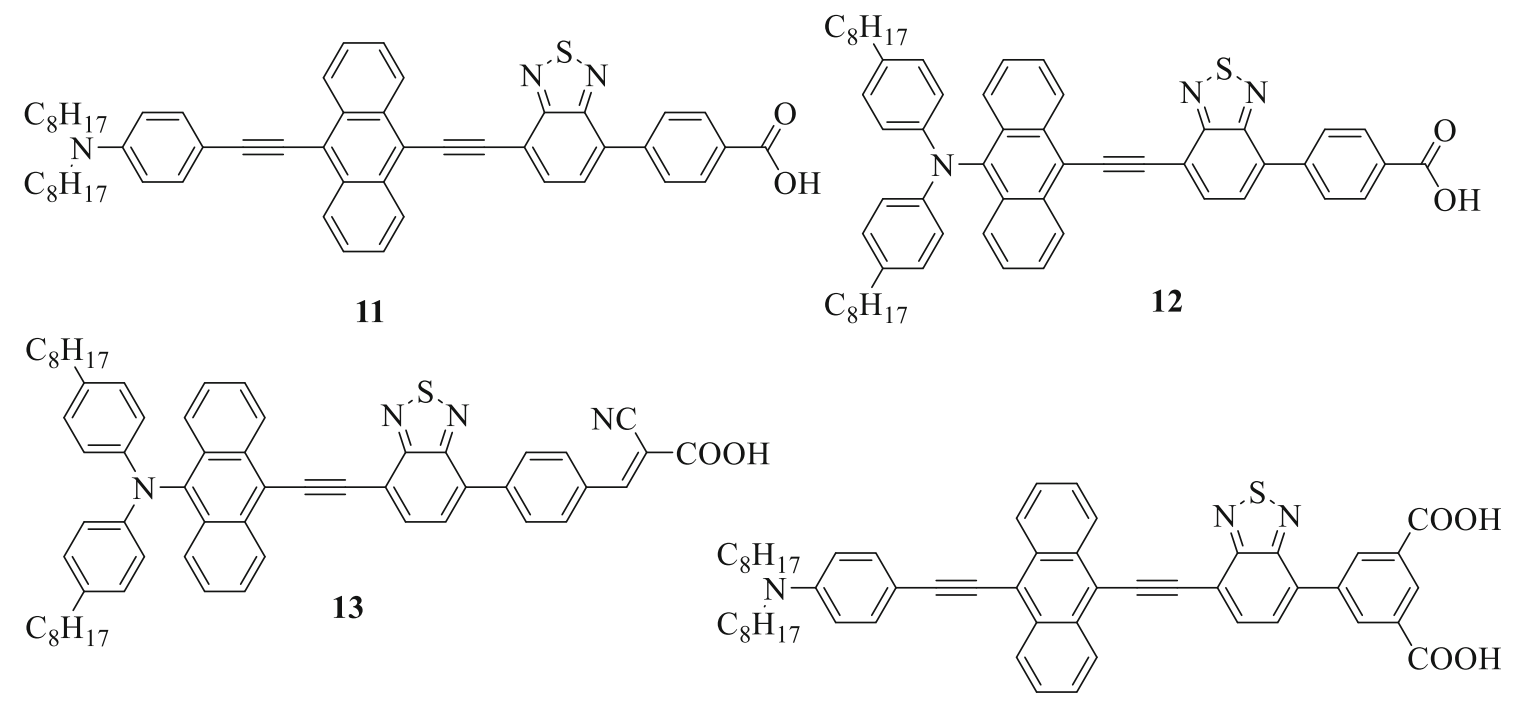<smiles>CCCCCN(CCCCC)c1ccc(C#Cc2c3ccccc3c(C#Cc3ccc(-c4ccc(C(=O)NO)cc4)c4nsnc34)c3ccccc23)cc1</smiles>

14

15
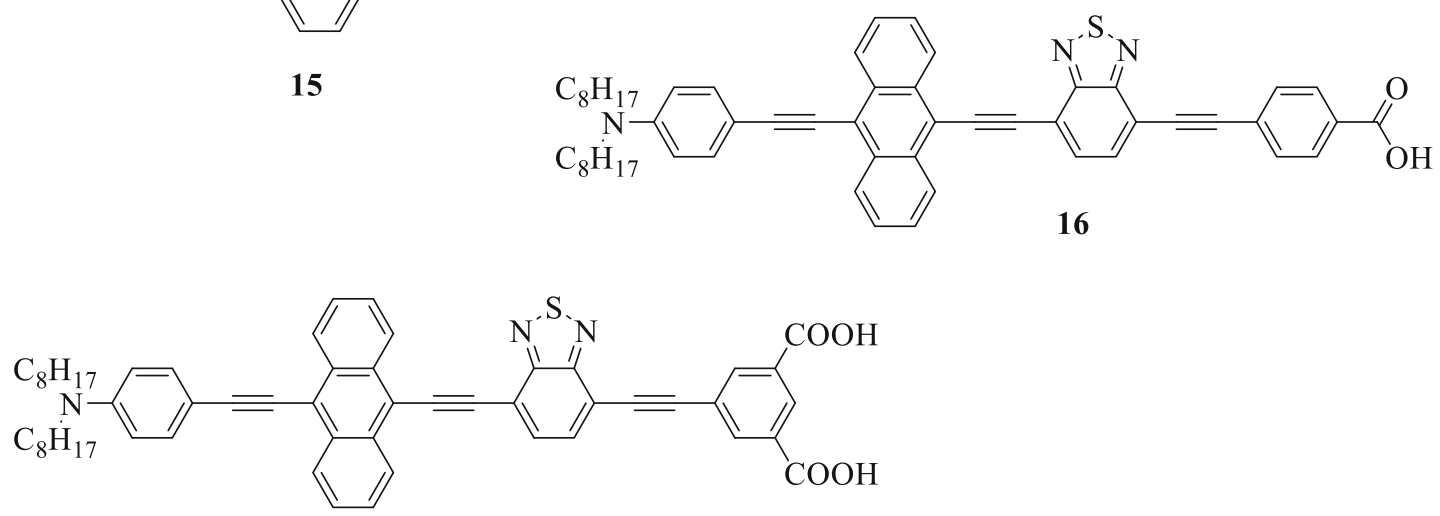

17

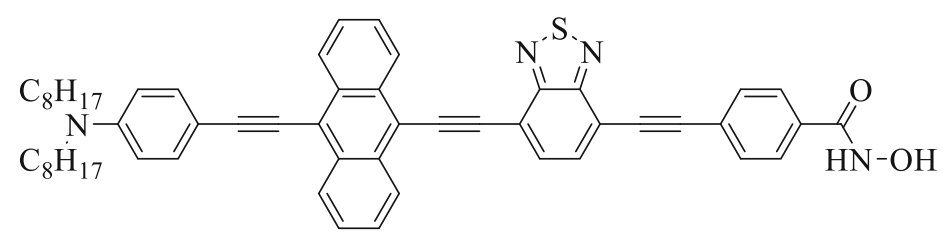




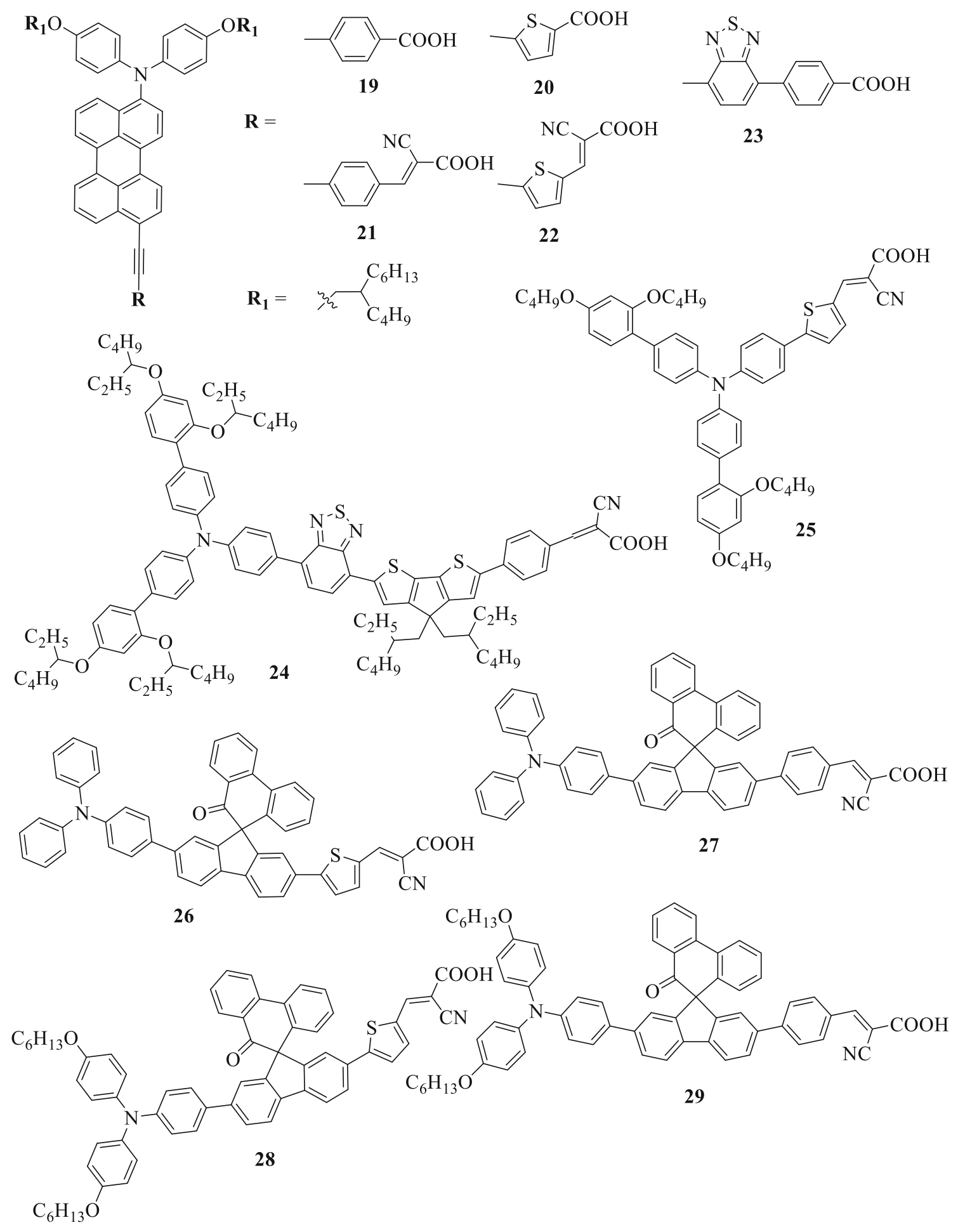



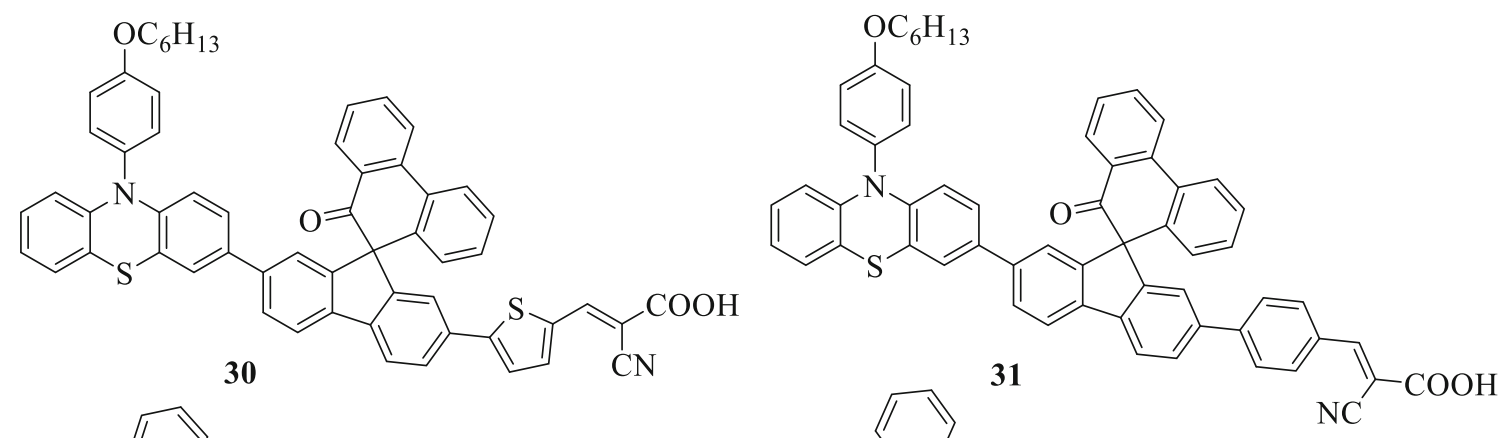<smiles>[R]C=C(C#N)C(=O)O</smiles><smiles>C=C(CCCCCCCCCCC#N)N(c1ccccc1)c1ccccc1</smiles>

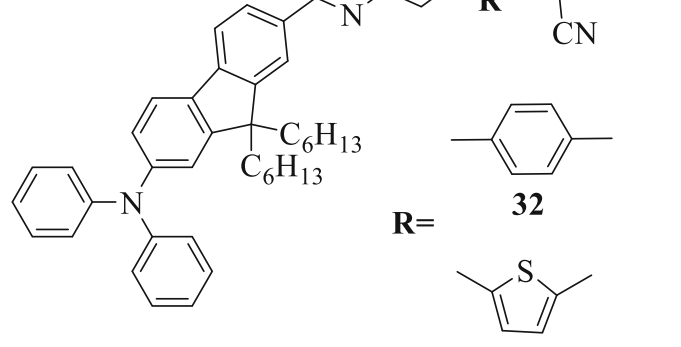

33

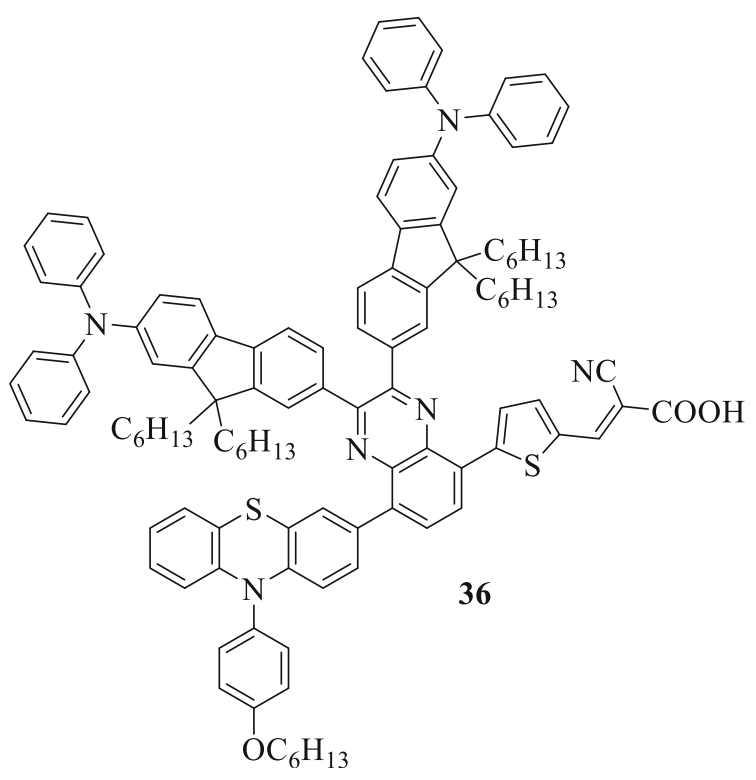

35<smiles>CCCCCOc1ccc(N2c3ccccc3Sc3cc(-c4ccc(-c5ccc(/C=C(\C#N)C(=O)O)s5)c5nc(-c6ccccc6)c(-c6ccccc6)nc45)ccc32)cc1</smiles> 
<smiles>C/C=C\CCCCC#N</smiles>

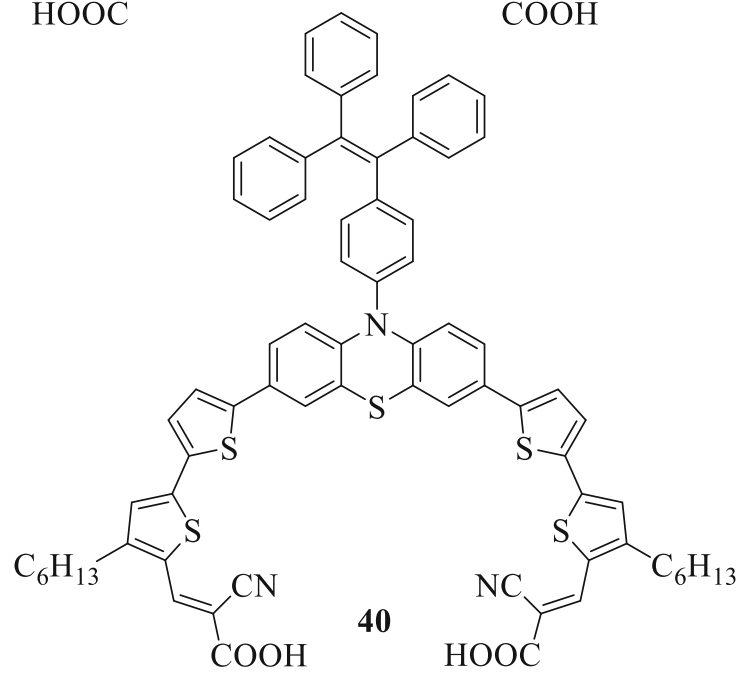

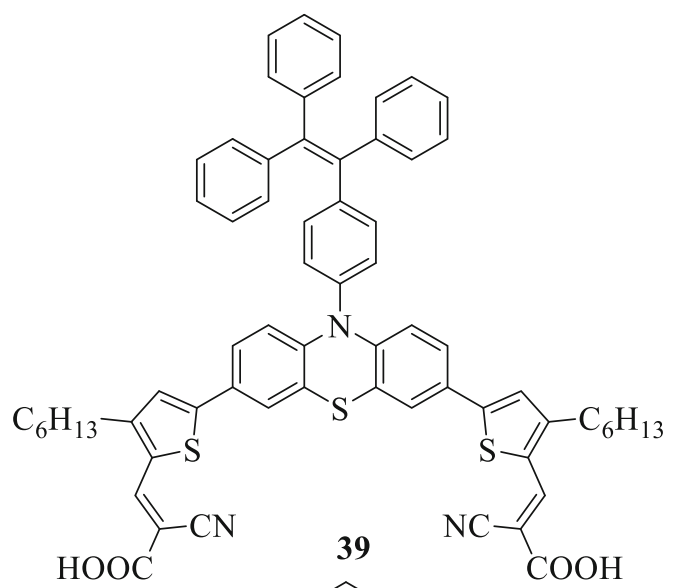

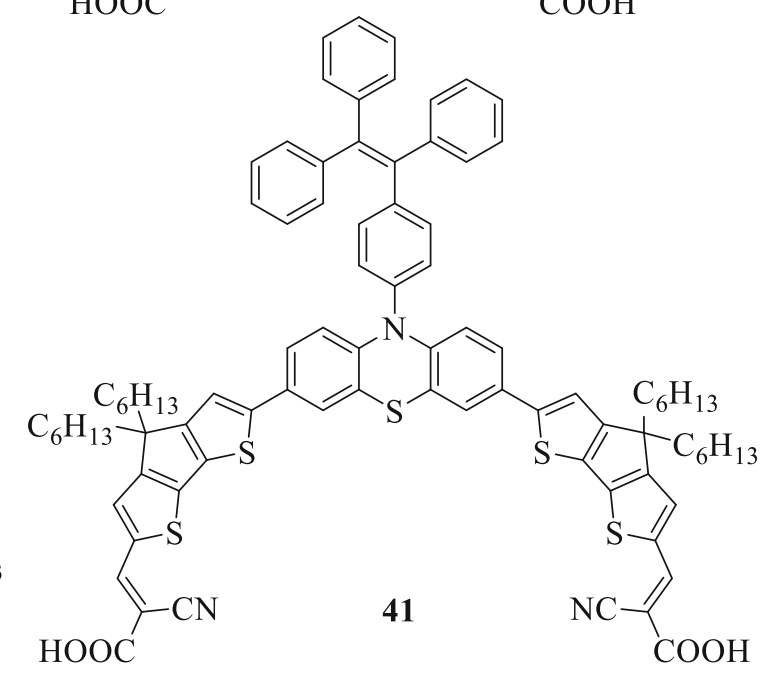

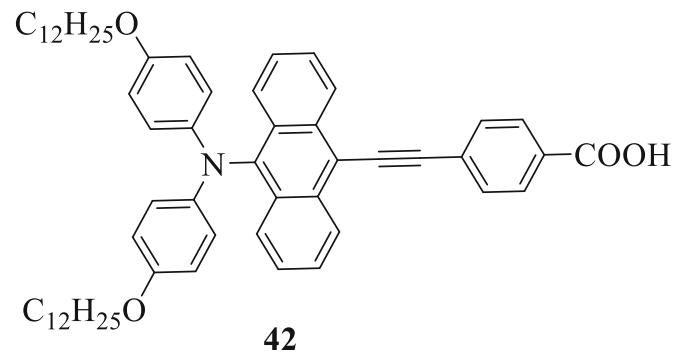

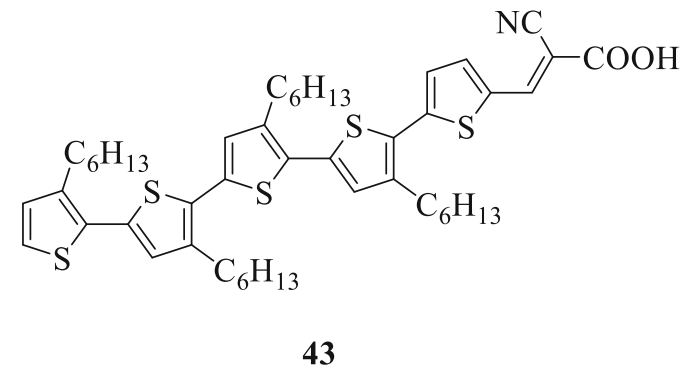




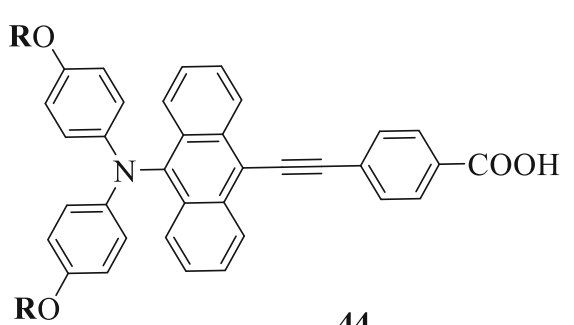

44
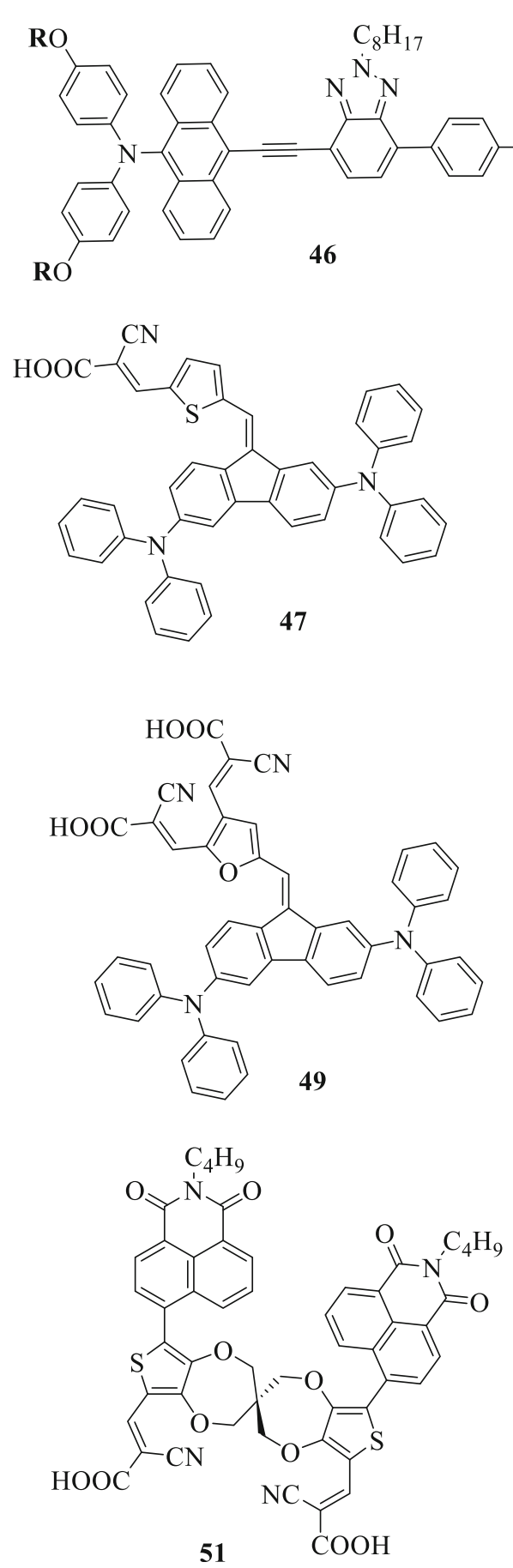

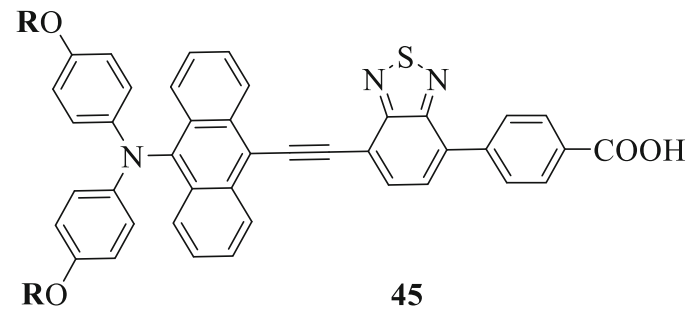

$$
\mathbf{R}=\text { - } \mathrm{C}_{6} \mathrm{H}_{13}
$$<smiles>N#CC(=Cc1ccc(C=C2c3cc(N(c4ccccc4)c4ccc5ccccc5c4)ccc3-c3ccc(N(c4ccccc4)c4ccc5ccccc5c4)cc32)s1)C(=O)O</smiles>

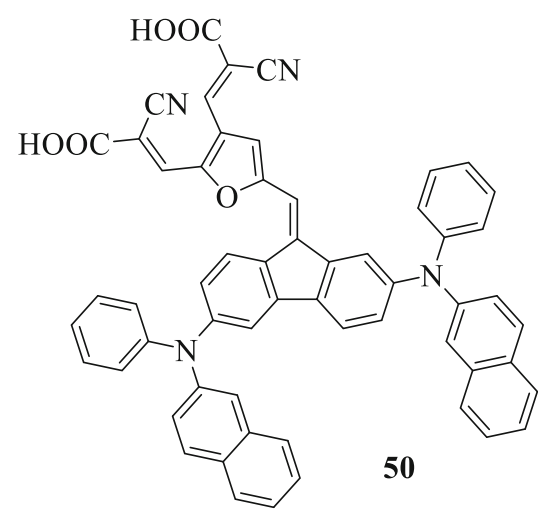




\section{CONCLUSION AND PERSPECTIVE}

In conclusion, the potential high demand for renewable energy supply for applications in low power consumption will significantly enhance the development of indoor DSSC technology. Recently, a number of attempts have been made to develop indoor DSSCs with a view to achieving highest efficiencies. Professionals from universities, researchers, government and the PV industry work relentlessly to produce new materials that can improve the performance of the indoor DSSC. This review explains the basics of DSSC and discusses recent progress in DSSC photoanodes, sensitizers, electrolytes, and CEs for indoor applications. Usually, indoor lights produce lower light intensity based on the design and lighting mechanisms, with varying emission spectra. Among the numerous indoor lighting sources, LED and fluorescent lamps are the most energy efficient light for our everyday lives, which in most indoor DSSC cases also displayed the highest efficiency because of their narrower spectral widths without the low-photonenergy infrared emission. Actually, most DSSCbased works have been assessed under a standard AM 1.5G condition. In fact, the various light sources are utilized across different types of labs and the illumination state of the indoor atmosphere is different, as is the characteristic of spectrum and intensity. To the best of our knowledge indoor DSSC lighting requirements are not standardized; this includes the light source type, light intensity, etc. No measuring system has yet been developed and validated for evaluating the characteristics of the indoor DSSC.

This review suggests that if sufficient consideration is paid to all four parts of DSSC through the use of highly efficient materials and development techniques, a high-efficiency indoor DSSC could be made and this could be of great commercial interest. For producing optimal dyes for indoor DSSC, it is desirable to raise the amount of alkyl chains on the sensitizers to lift the $\mathrm{V}_{\mathrm{OC}}$ of the device. The sensitizer's absorption range would also align with the indoor light emission spectra. The optimal dye under indoor lighting does not require either a long conjugation framework or a strong dipole because the emission spectrum of indoor light does not cover the NIR region as opposed to the solar spectrum. This dramatically lowers the synthetic costs of the dyes. Photoanode mesoporous layers should be modified in thickness and the light-scattering capacity to optimize light harvesting and decrease recombination loss. A compact blocking layer is also necessary to prevent electron leakage across a broad spectrum of intensities, allowing the DSSCs to function efficiently in low-light conditions. The long-term stability of the indoor DSSC will help a step towards its commercialization. The liquid electrolyte-based DSSCs show poor stability because of its electrolyte leakage, and organic solvent evaporation, leading to poor efficiency. The use of polymer based electrolyte could improve the stability of indoor DSSC. Polymers, low-cost nanoparticles, carbon materials or its composites with high catalytic activity, conductivity, and stability can be used as an alternative for Pt based CEs.

\section{FUNDING}

Open access funding provided by Manipal Academy of Higher Education, Manipal.

\section{CONFLICT OF INTEREST}

We have no conflict of interest to declare

\section{OPEN ACCESS}

This article is licensed under a Creative Commons Attribution 4.0 International License, which permits use, sharing, adaptation, distribution and reproduction in any medium or format, as long as you give appropriate credit to the original author(s) and the source, provide a link to the Creative Commons licence, and indicate if changes were made. The images or other third party material in this article are included in the article's Creative Commons licence, unless indicated otherwise in a credit line to the material. If material is not included in the article's Creative Commons licence and your intended use is not permitted by statutory regulation or exceeds the permitted use, you will need to obtain permission directly from the copyright holder. To view a copy of this licence, visit http://creativecommons.org/licenses/by/4.0/.

\section{REFERENCES}

1. G. Bazan, Electron. Green J. 1 (1997).

2. S. Ashina, J. Fujino, T. Masui, T. Ehara, and G. Hibino, Energy Policy 41, 584 (2012).

3. U. Ahmed, M. Alizadeh, N.A. Rahim, S. Shahabuddin, M.S. Ahmed, and A.K. Pandey, Sol. Energy 174, 1097 (2018).

4. M. Yoosuf, S.C. Pradhan, S. Soman, and K.R. Gopidas, Sol. Energy 188, 55 (2019).

5. H. Wu, X. Xie, J. Zhang, S. Li, Z. Shen, and Y. Yuan, J. Power Sources 451, 227748 (2020).

6. L. Han, Y. Chen, J. Zhao, Y. Cui, and S. Jiang, Tetrahedron 76, $131102(2020)$.

7. M.A. Green, Phys. E Low-Dimensional Syst. Nanostructures 14, 65 (2002).

8. N.D. Desai, S.S. Mali, R.M. Mane, V.B. Ghanwat, C.K. Hong, and P.N. Bhosale, J. Mater. Sci. Mater. Electron. 27, 11739 (2016).

9. S.S. Patil, R.M. Mane, S.S. Mali, C.K. Hong, and P.N. Bhosale, Sol. Energy 201, 102 (2020).

10. V.T. Chebrolu, and H. Kim, J. Mater. Chem. C 7, 4911 (2019).

11. H.A. Maddah, V. Berry, and S.K. Behura, Renew. Sustain. Energy Rev. 121, 109678 (2020).

12. I.M. Abdellah, and A. El-Shafei, Sol. Energy 198, 25 (2020).

13. N. Duvva, U. Chilakamarthi, and L. Giribabu, Sustain Energy Fuels 1, 678 (2017).

14. G. Wang, J. Deng, X. Wang, J. Liu, Y. Chen, and B. Liu, J. Mater. Sci. Mater. Electron. 30, 20525 (2019).

15. I. Repins, M.A. Contreras, B. Egaas, C. DeHart, J. Scharf, C.L. Perkins, B. To, and R. Noufi, Prog. Photovoltaics Res. Appl. 16, 235 (2008). 
16. K.L. Chopra, P.D. Paulson, and V. Dutta, Prog. Photovoltaics Res. Appl. 12, 69 (2004).

17. M. Saliba, T. Matsui, K. Domanski, J.-Y. Seo, A. Ummadisingu, S.M. Zakeeruddin, J.-P. Correa-Baena, W.R. Tress, A. Abate, A. Hagfeldt, and M. Gratzel, Science 354, 206 (2016).

18. J.J. Yoo, S. Wieghold, M.C. Sponseller, M.R. Chua, S.N. Bertram, N.T.P. Hartono, J.S. Tresback, E.C. Hansen, J.P. Correa-Baena, V. Bulović, T. Buonassisi, S.S. Shin, and M.G. Bawendi, Energy Environ. Sci. 12, 2192 (2019).

19. H. Ren, S. Yu, L. Chao, Y. Xia, Y. Sun, S. Zuo, F. Li, T. Niu, Y. Yang, H. Ju, B. Li, H. Du, X. Gao, J. Zhang, J. Wang, L. Zhang, Y. Chen, and W. Huang, Nat. Photonics 14, 154 (2020).

20. L. Zhou, J. Chang, Z. Liu, X. Sun, Z. Lin, D. Chen, C. Zhang, J. Zhang, and Y. Hao, Nanoscale 10, 3053 (2018).

21. J. Feng, X. Zhu, Z. Yang, X. Zhang, J. Niu, Z. Wang, S. Zuo, S. Priya, S. FrankLiu, and D. Yang, Adv. Mater. 30, 1 (2018).

22. B.O. Regan, and M. Gratzelt, Nature 353, 737 (1991).

23. C. Altinkaya, A. Atli, A. Atilgan, K. Salimi, and A. Yildiz, Int. J. Energy Res. 44, 3160 (2020).

24. M. Baro, Jaidev, and S. Ramaprabhu, Appl. Surf. Sci. 503, 144069 (2020)

25. X. Wang, A. Bolag, W. Yun, Y. Du, C. Eerdun, X. Zhang, T. Bao, J. Ning, H. Alata, and T. Ojiyed, J. Mol. Struct. 1206, 127694 (2020).

26. M.L. Jiang, J.J. Wen, Z.M. Chen, W.H. Tsai, T.C. Lin, T.J. Chow, and Y.J. Chang, Chem. Sus. Chem. 12, 3654 (2019).

27. T.S. Bramhankar, S.S. Pawar, J.S. Shaikh, V.C. Gunge, N.I. Beedri, P.K. Baviskar, H.M. Pathan, P.S. Patil, R.C. Kambale, and R.S. Pawar, J. Alloys Compd. 817, 152810 (2020).

28. K. Subalakshmi, and J. Senthilselvan, Sol. Energy 171, 914 (2018).

29. S.V. Kuppu, A.R. Jeyaraman, P.K. Guruviah, and S. Thambusamy, Curr. Appl. Phys. 18, 619 (2018).

30. C.Y. Tan, F.S. Omar, N.M. Saidi, N.K. Farhana, S. Ramesh, and K. Ramesh, Sol. Energy 178, 231 (2019).

31. S.M.J. Nabavi, B. Hosseinzadeh, M. Tajbakhsh, and H. Alinezhad, J. Mater. Sci. Mater. Electron. 29, 3270 (2018).

32. A. Aslam, U. Mehmood, M. H. Arshad, A. Ishfaq, J. Zaheer, A. U1 Haq Khan, and M. Sufyan, Sol. Energy 207, 874 (2020).

33. I. Mora-Seró, M. Saliba, and Y. Zhou, Sol. RRL 4, 1900563 (2020).

34. L. Meng, J. You, and Y. Yang, Nat. Commun. 9, 5265 (2018).

35. L. Qiu, L.K. Ono, and Y. Qi, Energy 7, 169 (2018).

36. I. Etxebarria, J. Ajuria, and R. Pacios, J. Photonics Energy $5,57214(2015)$

37. M. Grätzel, Inorg. Chem. 44, 6841 (2005).

38. C.-P. Lee, C.-T. Li, and K.-C. Ho, Mater. Today 20, 267 (2017).

39. U. Mehmood, Z. Malaibari, F.A. Rabani, A.U. Rehman, S.H.A. Ahmad, M.A. Atieh, and M.S. Kamal, Electrochim. Acta 203, 162 (2016).

40. S. Iwata, S. Shibakawa, N. Imawaka, and K. Yoshino, Energy Reports 4, 8 (2018).

41. L. Fraas and L. Partain, Solar cells and their applications: Second Edition (2010).

42. M. Freitag, J. Teuscher, Y. Saygili, X. Zhang, F. Giordano, P. Liska, J. Hua, S.M. Zakeeruddin, J.E. Moser, M. Grätzel, and A. Hagfeldt, Nat. Photonics 11, 372 (2017).

43. A.H. Ngu, M. Gutierrez, V. Metsis, S. Nepal, and Q.Z. Sheng, IEEE Internet Things J. 4, 1 (2017).

44. A. Raj, and D. Steingart, J. Electrochem. Soc. 165, B3130 (2018).

45. S. Venkatesan, I.P. Liu, C.W. Li, C.M. Tseng-Shan, Y.L. Lee, and A.C.S. Sustain, Chem. Eng. 7, 7403 (2019).

46. S. Biswas, and H. Kim, Polymers (Basel). 12, 1338 (2020).

47. A. Venkateswararao, J.K.W. Ho, S.K. So, S.-W. Liu, and K.T. Wong, Mater. Sci. Eng. R Rep. 139, 100517 (2020).
48. V. Sugathan, E. John, and K. Sudhakar, Renew. Sustain. Energy Rev. 52, 54 (2015).

49. L.L. Li, and E.W.G. Diau, Chem. Soc. Rev. 42, 291 (2013).

50. J.S. Luo, Z.Q. Wan, and C.Y. Jia, Chinese Chem. Lett. 27, 1304 (2016)

51. A. Mahmood, Sol. Energy 123, 127 (2016).

52. J. Gong, K. Sumathy, Q. Qiao, and Z. Zhou, Renew. Sustain. Energy Rev. 68, 234 (2017).

53. M.R. Narayan, Renew. Sustain. Energy Rev. 16, 208 (2011).

54. M.K. Nazeeruddin, E. Baranoff, and M. Grätzel, Sol. Energy 85, 1172 (2011).

55. M.E. Yeoh, and K.Y. Chan, Int. J. Energy Res. 41, 2446 (2017).

56. B. Roose, S. Pathak, and U. Steiner, Chem. Soc. Rev. 44, 8326 (2015).

57. S. Yun, Y. Qin, A.R. Uhl, N. Vlachopoulos, M. Yin, D. Li, X. Han, and A. Hagfeldt, Energy Environ. Sci. 11, 476 (2018).

58. J. Gong, J. Liang, and K. Sumathy, Renew. Sustaina. Energy Rev.

59. A. Hagfeldt, and M. Graetzel, Chem. Rev. 95, 49 (1995).

60. S. Rühle, and D. Cahen, J. Phys. Chem. B 108, 17946 (2004).

61. Y.-C. Chen, Y.-C. Chang, and C.-M. Chen, J. Electrochem. Soc. 165, F409 (2018).

62. K.W. Chen, L.S. Chen, and C.M. Chen, J. Mater. Sci. Mater. Electron. 30, 15105 (2019).

63. J.C. Chou, C.H. Kuo, P.Y. Kuo, C.H. Lai, Y.H. Nien, Y.H. Liao, C.C. Ko, C.M. Yang, and C.Y. Wu, IEEE J. Photovoltaics 9, 926 (2019).

64. C. Hora, F. Santos, M.G.F. Sales, D. Ivanou, A. Mendes, and A.C.S. Sustain, Chem. Eng. 7, 13464 (2019).

65. I.P. Liu, W.H. Lin, C.M. Tseng-Shan, Y.L. Lee, and A.C.S. Appl, Mater. Interfaces 10, 38900 (2018).

66. Y.-H. Nien, H.-H. Chen, H.-H. Hsu, M. Rangasamy, G.-M. Hu, Z.-R. Yong, P.-Y. Kuo, J.-C. Chou, C.-H. Lai, C.-C. Ko, and J.-X. Chang, Energies 13, 2248 (2020).

67. S. Sasidharan, S. C. Pradhan, A. Jagadeesh, B. N. Nair, A. A. P. Mohamed, N. U. K. N, S. Soman, and U. N. S. Hareesh, ACS Appl. Energy Mater. 3, 12584 (2020).

68. C.Y. Chen, Z.H. Jian, S.H. Huang, K.M. Lee, M.H. Kao, C.H. Shen, J.M. Shieh, C.L. Wang, C.W. Chang, B.Z. Lin, C.Y. Lin, T.K. Chang, Y. Chi, C.Y. Chi, W.T. Wang, Y. Tai, M. De Lu, Y.L. Tung, P.T. Chou, W.T. Wu, T.J. Chow, P. Chen, X.H. Luo, Y.L. Lee, C.C. Wu, C.M. Chen, C.Y. Yeh, M.S. Fan, J. De Peng, K.C. Ho, Y.N. Liu, H.Y. Lee, C.Y. Chen, H.W. Lin, C. Te Yen, Y.C. Huang, C.S. Tsao, Y.C. Ting, T.C. Wei, and C.G. Wu, J. Phys. Chem. Lett. 8, 1824 (2017).

69. C.H. Huang, Y.W. Chen, C.M. Chen, and A.C.S. Appl, Mater. Interfaces 10, 2658 (2018).

70. T.D. Nguyen, C.H. Lin, C.L. Mai, and C.G. Wu, ACS Omega 4, 11414 (2019).

71. C.V. Jagtap, V.S. Kadam, S.R. Jadkar, and H.M. Pathan, ES Energy Environ. 3, 60 (2019).

72. J.L. Lan, T.C. Wei, S.P. Feng, C.C. Wan, and G. Cao, J. Phys. Chem. C 116, 25727 (2012).

73. S. Venkatesan, W.H. Lin, H. Teng, Y.L. Lee, and A.C.S. Appl, Mater. Interfaces 11, 42780 (2019).

74. S. Venkatesan, I.P. Liu, J.C. Lin, M.H. Tsai, H. Teng, and Y.L. Lee, J. Mater. Chem. A 6, 10085 (2018).

75. I.P. Liu, W.N. Hung, H. Teng, S. Venkatesan, J.C. Lin, and Y.L. Lee, J. Mater. Chem. A 5, 9190 (2017).

76. S. Venkatesan, S.C. Su, W.N. Hung, I.P. Liu, H. Teng, and Y.L. Lee, J. Power Sources 298, 385 (2015).

77. S.J. Seo, H.J. Cha, Y.S. Kang, and M.S. Kang, Electrochim. Acta 145, 217 (2014).

78. S. Venkatesan, I.P. Liu, W.N. Hung, H. Teng, and Y.L. Lee, Chem. Eng. J. 367, 17 (2019).

79. S. Venkatesan, I. P. Liu, C. M. Tseng Shan, H. Teng, and Y. L. Lee, Chem. Eng. J. 394, 124954 (2020).

80. I.-P. Liu, Y.-Y. Chen, Y.-S. Cho, L.-W. Wang, C.-Y. Chien, and Y.-L. Lee, J. Power Sources 482, 228962 (2021).

81. M. Wu, and T. Ma, Chem. Sus. Chem. 5, 1343 (2012). 
82. M. Wu, X. Lin, Y. Wang, L. Wang, W. Guo, D. Qi, X. Peng, A. Hagfeldt, M. Grätzel, and T. Ma, J. Am. Chem. Soc. 134, 3419 (2012)

83. M.H. Yeh, L.Y. Lin, C.P. Lee, H.Y. Wei, C.Y. Chen, C.G. $\mathrm{Wu}$, R. Vittal, and K.C. Ho, J. Mater. Chem. 21, 19021 (2011).

84. C.P. Lee, C.A. Lin, T.C. Wei, M.L. Tsai, Y. Meng, C.T. Li, K.C. Ho, C.I. Wu, S.P. Lau, and J.H. He, Nano Energy 18, 109 (2015).

85. Y.J. Huang, H.T. Chen, S.B. Ann, C.T. Li, J.T. Lin, C.P. Lee, and K.C. Ho, J. Mater. Chem. A 7, 26089 (2019).

86. Y.J. Huang, Y.J. Lin, H.J. Chien, Y.F. Lin, and K.C. Ho, Nanoscale 11, 12507 (2019).

87. A. Mishra, M.K.R. Fischer, and P. Büuerle, Angew. Chemie Int. Ed. 48, 2474 (2009).

88. J.M. Ji, H. Zhou, and H.K. Kim, J. Mater. Chem. A 6, 14518 (2018).

89. C.H. Chen, P.T. Chou, T.C. Yin, K.F. Chen, M.L. Jiang, Y.J. Chang, C.K. Tai, and B.C. Wang, Org. Electron. 59, 69 (2018).

90. M. B. Desta, N. S. Vinh, C. Pavan Kumar, S. Chaurasia, W. T. Wu, J. T. Lin, T. C. Wei, and E. Wei-Guang Diau, J. Mater. Chem. A 6, 13778 (2018).

91. M.C. Tsai, C.L. Wang, C.W. Chang, C.W. Hsu, Y.H. Hsiao, C.L. Liu, C.C. Wang, S.Y. Lin, and C.Y. Lin, J. Mater. Chem. A 6, 1995 (2018)
92. M. C. Tsai, Y. C. Chiu, M. De Lu, Y. L. Tung, H. C. Tsai, J. R. Chang Chien, and C. Y. Lin, ACS Appl. Energy Mater. 3, 2744 (2020).

93. H.H. Chou, Y.C. Liu, G. Fang, Q.K. Cao, T.C. Wei, C.Y. Yeh, and A.C.S. Appl, Mater. Interfaces 9, 37786 (2017).

94. R. Y. Huang, W. H. Tsai, J. J. Wen, Y. J. Chang, and T. J. Chow, J. Power Sources 458, 228063 (2020).

95. C.T. Li, Y.L. Kuo, C.P. Kumar, P.T. Huang, and J.T. Lin, J. Mater. Chem. A 7, 23225 (2019).

96. K.S.K. Reddy, Y.C. Chen, C.C. Wu, C.W. Hsu, Y.C. Chang, C.M. Chen, C.Y. Yeh, and A.C.S. Appl, Mater. Interfaces 10, 2391 (2018).

97. E. Tanaka, H. Michaels, M. Freitag, and N. Robertson, J. Mater. Chem. A 8, 1279 (2020).

98. Y. S. Tingare, N. S. n. Vinh, H. H. Chou, Y. C. Liu, Y. S. Long, T. C. Wu, T. C. Wei, and C. Y. Yeh, Adv. Energy Mater. 7, 30 (2017).

99. Y.C. Chen, G.W. Huang, Y.J. Chang, and J.J. Wen, J. Mater. Sci. Mater. Electron. 30, 12981 (2019).

100. M. Chandra Sil, L.-S. Chen, C.-W. Lai, Y.-H. Lee, C.-C. Chang, and C.-M. Chen, J. Power Sources 479, 229095 (2020).

Publisher's Note Springer Nature remains neutral with regard to jurisdictional claims in published maps and institutional affiliations. 